\title{
MUJER Y TRAVESTISMO EN EL TEATRO DE CALDERÓN
}

Rosa ANA Escalonilla LóPEZ

Actualmente, las posturas críticas ęn torno a la figura femenina en la dramaturgia calderoniana siguen abocadas al debate, aunque cada vez son más los estudiosos que descubren en Calderón al dramaturgo moderno y vanguardista. Se plantean nuevas visiones en la aproximación a este aspecto con respecto a otras pretéritas más parciales ${ }^{1}$. Sin embargo, a pesar del cambio de visión que se viene observando en los últimos años acerca del tema de la mujer en Calderón ${ }^{2}$, siguen existiendo posturas que lo acercan a una visión negativa de lo femenino en diversos grados, y no sólo como recurso cómico, como convención teatral o como mecanismo solapado para expresar críticas frente a un público conservador, sino como pretendido reflejo de su ideología. Entre éstos se hallan investigadores que han evolucionado desde posiciones ciertamente feministas hasta una actitud interrogante acerca de los verdaderos fines ideológicos de Calderón, como Frederick de Armas (1993). En otras ocasiones se admite una crítica abierta contra la mujer por parte de Calderón, pero basada en el impacto cómico. Es el caso de Elisa M. ${ }^{a}$ Domínguez de Paz (1996). También es común el punto de vista intermedio entre la valoración de la mujer en la comedia y el mantenimiento dentro de un marco conservador en los dramas, como Ángel Facio (1997). O la visión negativa de la mujer en los autos y positiva en dramas y comedias, como Jacinto Rivera de Rosales (1997). Finalmente, existen posiciones que consideran la misoginia de Calderón, bien en dramas, como es el caso de Elena Gascón Vera (1992), bien en teatro breve, como Javier Huerta Calvo (1995).

En cuanto al travestismo en la obra de Calderón, contamos con estudios generales sobre este recurso en la totalidad del teatro del Siglo de

\footnotetext{
1 Recordemos, por ejemplo, las afirmaciones peyorativas de Menéndez Pelayo sobre los tipos femeninos calderonianos (1910).

2 Entre éstos, podemos destacar nombres que van a ser mencionados a lo largo de este estudio. Entre ellos, por ejemplo, José Amezcua, Marie-Françoise Déodat-Kessedjian, Melveena Mckendrick, M. ${ }^{a}$ Josefa Porro, Antonio Regalado, etc.
} 
Oro. Hemos de mencionar el breve estudio de Romera Navarro (1934) sobre las disfrazadas de varón en la comedia. En segundo lugar, el ya clásico de Carmen Bravo-Villasante (1976) sobre la mujer vestida de hombre, que se constituye como referencia imprescindible para los estudiosos del tema. Se realiza un estudio descriptivo de las obras más representativas del disfraz varonil y un breve esbozo del disfraz femenino. En tercer lugar debemos nombrar a Jean Canavaggio (1979). En su estudio analiza brevemente las circunstancias y modalidades de algunos disfrazados de mujer en el teatro barroco español. También existen estudios que tocan el tema de manera tangencial, como es el caso de Ignacio Arellano (1986) y Ruano de la Haza (1994a) o desde el punto de vista del estudio crítico o concreto de una sola obra, como por ejemplo, Manuel Abad (1985), Mason (1985) y Ángel Martínez Blasco (1995), entre otros.

En este estudio tratamos de poner de manifiesto la estrecha relación existente entre el recurso del travestismo, como artificio de expresión crítica, y el tema de la mujer en el teatro de Calderón desde una dimensión moderna y transgresora.

Si bien el travestismo ${ }^{3}$ aparece como recurso de gran profusión en la escena dramática del Siglo de $\mathrm{Oro}^{4}$, en las tablas barrocas calderonianas se convierte, no sólo en elemento unificador de toda su dramaturgia ${ }^{5}$ (es empleado en comedias, autos sacramentales y piezas breves), sino también en símbolo de su teatro y en mecanismo de transmisión ideológica. No debemos olvidar que nos hallamos ante un espectáculo de naturaleza básicamente histriónica, aunque también hemos de señalar que no se trata de un hecho aislado, sino instalado dentro de un conjunto histórico y sociocultural globalizado, en el cual aparecen amalgamados los distintos aspectos que componen el calidoscopio del hecho teatral. Sólo una posterior sistematización permite retomar el análisis de las distintas perspectivas que confluyen en su configuración: desde la acción argumental hasta las manifestaciones ideológicas, pasando por los recursos escénicos y cómicos, todos ellos son elementos configuradores del travestismo, inseparables en el momento de la representación, pero dotados de entidad propia en el mo-

${ }^{3}$ Según el Diccionario de la Real Academia Española, travestir es «vestir a una persona con la ropa del sexo contrario».

4 Los títulos dramáticos del Siglo de Oro en que aparecen mujeres vestidas de hombre fueron recogidos por Carmen Bravo-Villasante (1976). Aunque la lista no se halla completa, sí sirve este estudio pionero como reflejo del extenso empleo que los dramaturgos del Siglo de Oro dieron a este recurso: Lope de Vega, Tirso de Molina, Calderón de la Barca, Rojas, Moreto, etc. Jean Canavaggio (1979), como hemos señalado más arriba, recoge algunas de las obras en que aparece el recurso inverso, es decir, el del hombre disfrazado de mujer, en la comedia.

5 Véase la relación de obras de Calderón en que aparece el recurso del travestismo en p. 79. 
mento de su estudio. En este caso nos centraremos en la que consideramos una de las principales funciones del recurso del travestismo calderoniano: la ideológica. Y dentro de ella: el tema de la mujer.

La presencia del travestismo en las tablas añadía al paisaje escénico áureo un atractivo componente erótico por lo ajustado de las prendas que habían de vestir las actrices al asumir la identidad varonil. Su visión era causa de censura ante los sectores más reaccionarios e intolerantes. En el actor, el travestismo representaba también un elemento de subversión por sugerir indirectamente actitudes sexuales prohibidas y hasta condenadas en aquella sociedad, aunque su menor aparición en la escena nos hace suponer una clara desventaja frente a las disfrazadas. Pero no sólo era la vestimenta la culpable de las polémicas y diatribas ${ }^{6}$ que el travestismo llegó a originar. Su aparición llevaba consigo, además, la transgresión de los comportamientos estereotipados para hombres y mujeres. Algunos críticos, como ha señalado Catherine Connor (1994), sólo aceptan la existencia de transgresión si existen cambios obvios, y no sutiles, de actitud, pero lo cierto es que después del disfraz, el resultado no era el regreso al estado previo, sino la aparición de una repercusión desestabilizadora. Efectivamente, los papeles femeninos violentaban, mediante la excusa del travestismo, las restricciones que imponía la sociedad basándose en el poder omnímodo de la costumbre y de los rancios códigos que regían, sin embargo, la esencia de la vida cotidiana. Era lógico, por tanto, que la mayor conmoción y el mayor atractivo frente al público barroco procediera del travestismo femenino, si tenemos en cuenta su inserción en una sociedad conservadora que incorporaba una distinción del ser humano basada prioritariamente en su sexo. Los continuos ataques al travestismo no pudieron impedir su aparición cada vez más profusa y complicada en la escena áurea, pues al público le entusiasmaba y acudía masivamente a las representaciones. Es cierto que, por su extensa utilización y por su poder garantizador de éxito, el travestismo funcionó como convención dramática, pero también lo es que,

6 La controversia del disfraz varonil, así como los demás aspectos polémicos del teatro, fueron reflejados por autores de la época como Francisco de Barreda [1622] o Bances Candamo [1690]. Ya en el siglo XX, estos testimonios fueron recopilados por Cotarelo (1904). Y en nuestros días por otros investigadores como Sánchez Escribano y Porqueras Mayo (1972), Duncan Moir (1970), o Ana Suárez Miramón (1993a). Recordemos que desde 1608 existen reglamentos que prohiben que las mujeres salgan a bailar o a representar en hábito de hombre y que tal prohibición se repite en 1615 y en 1641 (Recogido por Varey, 1971: 48, 56 y 92). Algunos años más tarde, en 1644 y 1646, mueren la reina doña Isabel, primera mujer de Felipe IV y el príncipe Baltasar. Con este motivo, señala Casiano Pellicer [1804], resucitaron las polémicas y el Consejo de Castilla formuló una orden en que aconsejaba que se suspendieran las comedias, pero ponía como condición en caso de representarse, que las mujeres no se vistiesen de hombres y que sacasen las basquiñas hasta los pies (Edición de Díez Borque, 1975: 150. Véase también Cotarelo, 1904: 164). 
mediante éste, el dramaturgo podía transmitir determinadas cualidades a las criaturas histriónicas por él creadas. Así, Calderón se nos revela, a través del travestismo, como un hombre de ideas novedosas e incluso precursor de la modernidad frente a la ideología reaccionaria de múltiples sectores de la sociedad barroca. Este recurso le sirvió para la presentación de unas determinadas ideas y críticas hacia la sociedad contemporánea a través, precisamente, de los convencionalismos dramáticos. Entre ellas adquiere especial relevancia su visión de la mujer, que recibe un tratamiento bidimensional, enfocado bien desde la perspectiva del reflejo y la denuncia de su situación sociocultural, bien desde el punto de vista de la reivindicación. En este sentido, nuestro dramaturgo manifiesta su compromiso con un movimiento que estaba sucediendo en una reducida parte de la sociedad, consistente en la incorporación paulatina de las mujeres a espacios y actividades que venían reservándose hasta entonces exclusivamente para los hombres, como por ejemplo las de ámbito intelectual ${ }^{7}$. La forma de abordar estos temas en el tablado no era de forma clara y directa, sino a través del empleo alternativo de dos planos: el de la comedia y el de la ficción. En el primero se presentan los elementos que conducen al personaje hacia la impostura del disfraz. El segundo se halla propiciado, primordialmente, por el disfraz, que alcanza el nivel de recurso metaliterario, pues supone la aparición del teatro dentro del teatro ${ }^{8}$ y otorga a la escena una dimensión ficticia. En este plano el dramaturgo pone de manifiesto sus críticas y su ideología. También es de destacar la presencia en el es-

7 El acceso a la cultura escrita por parte de algunas mujeres del siglo XVII y, mediante ésta, a una participación social destacada ha sido puesto de relieve por diversos investigadores mediante la referencia y recopilación de testimonios directos. Entre ellos, M. ${ }^{a}$ Gloria Ródenas y Susana M. ${ }^{a}$ Vicent. Éstas también han señalado, sin embargo, que se trata de grupúsculos reducidos en una situación socio-económica determinada, ya que el grueso de la población se nutría de las clases subalternas que permanecieron en el anonimato por el desconocimiento de la escritura (1992: 22). En el prólogo a la obra de M." Josefa Porro, Danièle Bussy Genevois alude a la existencia de mujeres escritoras que primero fueron lectoras y hace referencia al debate que provocó la lectura femenina sobre la moralidad y las tareas propias de su sexo. Este primer acercamiento a la cultura es reflejo de un intento de reivindicación femenina (1995: 12 y 13). Iris Zavala, por su parte, señala la afición de algunas mujeres a participar en Justas y Certámenes poéticos (1995: 247). Margarita Ortega López menciona el anhelo femenino de romper con la educación desigual y el deseo existente en toda Europa de incrementar la educación de las mujeres (1997: 291). Véase también al respecto, Margarita Nelken, 1930; M. ${ }^{a}$ del Pilar Oñate, 1938; Jean Raymond Lanot, 1979; Díez Borque, 1979; VVAA. 1986; Mariló Vigil, 1986; VVAA. 1987; Sonja Herpoel, 1989; Ángeles Maeso, 1989; Nora Catelli, 1991; Isabel Barbeito, 1992; VVAA. 1992; Margaret L. King, 1993; M. ${ }^{a}$ del Mar Graña, 1994; Pilar Ballarín, 1994; Bolufer, 1994; Victoria Camps, 1994; Giulia Calvi, 1995; M. ${ }^{2}$ Grazia Profeti, 1995; M. Ángeles Calero, 1996; Cristina Segura Graíño, 1997 y 1998 , entre otros.

8 Es preciso mencionar el clásico estudio de Emilio Orozco (1969) que, a pesar de contar con tres décadas de antigüedad, sigue gozando de plena vigencia. 
cenario de una mujer fuerte, varonil y segura de sí misma incluso antes de vestirse con el disfraz masculino. Y ésta constituye la gran novedad y el gran atrevimiento de Calderón, pues mediante este enfoque calidoscópico del ser humano femenino su teatro adquiere connotaciones de modernidad. Incluso algunos investigadores, haciendo uso de un concepto actual y salvando las oportunas distancias, han hablado del feminismo ${ }^{9}$ calderoniano. En su teatro se percibe claramente un tratamiento de igualdad de todo ser humano independientemente de su sexo. Hay que tener en cuenta también que en la época de Calderón la censura perdió parte de la fuerza de periodos anteriores ${ }^{10}$ y que nuestro dramaturgo contaba con el apoyo de la Casa Real y del conde duque de Olivares ${ }^{11}$.

A pesar de esta dimensión ciertamente moderna desde la cual es presentado el personaje femenino calderoniano como ser variado y diverso, no debemos olvidar que nuestro dramaturgo se halla instalado en el seno de una sociedad preminentemente masculina y conservadora. Ha de valerse de ciertos recursos para incardinar en ella sus propuestas de reivindicación femenina. El travestismo se convierte así, desde la perspectiva ideológica, en recurso primordial de la comedia para la presentación de diversos aspectos relacionados con el tema de la mujer ante el espectador barroco:

1. La idea de una mujer situada fuera de los estereotipos de la época, pero mediante mecanismos de la vida cotidiana que le permiten insertar determinadas conductas progresistas y rebeldes de las disfrazadas en el marco de la ideología conservadora existente. Es la manera, por una parte, de poder presentar el tema sin escandalizar y, por otra, de que el público comprenda lo que ve en escena a través de signos que le son familiares por recurrentes y por cotidianos. Contrariamente a lo que opina Becker ${ }^{12}$, consideramos que la función principal de la vestimenta varonil en el ámbito ideológico es la de erigirse en síntoma de feminismo reivin-

9 Según Antonio Regalado, «el feminismo» de Calderón se hace patente en su afinidad y profunda simpatía por la mujer, víctima continua de los excesos del honor y los celos, la autoridad paterna y las convenciones sociales (1995, I: 984).

10 Acerca del apaciguamiento de las dos polémicas que habían predominado durante el desarrollo de la comedia nueva: la estética que enfrentaba a antiguos y modernos y la ética sobre la licitud del teatro, véase, por ejemplo, Marc Vitse, 1995: 197.

${ }^{11}$ Véase sobre todo, por lo reciente, J. H. Elliot y L. W. B. Brockliss (1999) sobre la creciente influencia de los ministros-privados en las cortes europeas de los siglos XVI y XVII. Véase también, por ejemplo, Othón Arróniz, 1977 y Teófilo de Lozoya, 1990.

${ }_{12}$ A raíz de lo apuntado por Jean Canavaggio, Becker precisa que «el disfraz varonil de la mujer se percibe como valorizante y grato y para nada señal de feminismo reivindicador» (Jean Canavaggio, 1979: 148). Luis M. González González va aún más lejos, señalando que el disfraz varonil esconde, en ocasiones, una misoginia terrible. Sin embargo, con respecto a las disfrazadas de Calderón apunta que transgredían lo que constituía el orden normal de las cosas (1994-95). 
dicador. Efectivamente, muchos de los disfraces, como veremos a continuación, representan la exigencia de un derecho fundamental de las mujeres como seres humanos: tomar decisiones sobre su propia existencia y, por tanto, sobre las cuestiones de amor y de honor. Pero no debemos olvidar que ellas viven en una realidad social que no permite, al menos abiertamente, la realización de acciones de esa naturaleza a una mujer. Por eso, todas ellas se valen de un recurso clarividente y eficaz: el disfraz varonil. Cada disfrazada adopta una forma de expresar ese feminismo reivindicador:

1.1. Algunas mujeres calderonianas se convierten en defensoras de su propio honor ${ }^{13}$. Es el caso de Julia (La devoción de la cruz), Rosaura (La vida es sueño), Ismenia (Los tres afectos de amor) y La Culpa (El gran mercado del mundo). Todas ellas coinciden en su opción de no dejar esa responsabilidad en manos masculinas, como era lo habitual en aquella época. Y es que, como señaló Américo Castro (1972: 60), en el siglo XVII el patrimonio de los bienes auténticamente valorables para el español se centraba primordialmente en la seguridad honrosa y la hombría. Por otra parte, el código del honor reafirmaba el poder de unos grupos sobre otros y constituía un mecanismo de mantenimiento de un orden en crisis ${ }^{14}$. El disfraz, por tanto, le va a servir a la mujer para defender una parcela de su vida que considera suya y de la cual se siente única responsable. En La devoción de la cruz Calderón nos presenta a una dama que transgrede el encierro monástico para ir tras el hombre que ama. El disfraz varonil le dará la oportunidad de realizar acciones que no podría llevar a cabo siendo mujer, ya que ser hombre en la realidad de entonces era una ventaja social y un valor en alza y permitía acciones que siendo fémina eran impensables ${ }^{15}$. Así, por ejemplo, los hombres gozaban de libertad de movi-

13 Este rasgo de algunos personajes femeninos barrocos ha sido señalada por múltiples investigadores desde Américo Castro, 1916, hasta otros autores de nuestros días como Julio Caro Baroja, 1968; Valentina Fernández Vargas, 1983; Ciriaco Morón Arroyo, 1982; Juan Ignacio Gutiérrez Nieto, 1983; Everett W. Hesse, 1987; Antonio Regalado, 1995, I y J. M. Losada Goya, 1993a, 1993b y 1997, entre otros.

14 Ésta es la idea en la que ha venido insistiendo la crítica hace años, desde la ya considerada clásica hasta la más reciente. Así, por ejemplo, J. A. Maravall hace ya dos décadas destacaba que el honor se reafirma en aquel nivel en el que puede verse amenazado (1979: 66). En la misma línea, Mariló Vigil sostuvo que el código del honor poseía una función de defensa del poder de unos grupos sobre otros y que contribuía al mantenimiento de un orden que estaba siendo sometido a graves tensiones (1986: 146). Margarita Ortega López considera en un trabajo reciente que en la cuestión del honor se estaba poniendo en juego todo un sistema de organización y transmisión del poder de esa sociedad (1997: 250).

15 Como señala Charles Vincent Aubrun, «el traje masculino da fama y honor a la mujer que se disfraza con él» (1968: n. 1, 209). 
mientos, que constituía uno de los principales aspectos de la reivindicación femenina de la época, y tenían libertad para elegir su propio destino. Maravall (1979: 127) piensa que durante la crisis renacentista, el afán individualista afectó también a la mujer, quien dio muestras de inquietud. Pero éstas no fueron bien vistas por los más severos moralistas al servicio de la consolidación del orden jerárquico señorial y ello repercutió en una renovada descalificación del sexo femenino.

Mediante el disfraz, las mujeres calderonianas superan los obstáculos que pueden hallar en la realización de sus inquietudes. A Julia le permite adentrarse en el universo masculino de los bandoleros en busca de su amante y le proporciona la ocasión de dar rienda suelta a su anhelo de venganza retando a Eusebio a luchar. En el plano de la comedia ya habíamos asistido a los acontecimientos propiciatorios de una actitud justificada desde el desarrollo de los mismos. Cómo sabemos, el honor de una dama incumbía por entero a su padre y a su hermano, pero al ser abandonada por Eusebio, Julia no puede recurrir a su hermano, ya que éste murió precisamente tratando de vengar la perdida honra de su hermana, ni a su padre, pues su autoritarismo le conduciría al asesinato de su propia hija. Por tanto, la soledad en que se halla constituye el resorte de actuación de esta dama en la defensa de su propio honor disfrazada de hombre ${ }^{16}$.

También Rosaura, la disfrazada de La vida es sueño, expresa su reivindicación femenina mediante la defensa de su honor. Ella representa la fuerza positiva de éste, como medio del individuo para preservar su propia identidad ${ }^{17}$. A través de las palabras de la disfrazada sabemos que ha sido alentada por su madre, Violante, para viajar hasta Polonia en busca de su olvidadizo amante, Astolfo, y de su padre, Clotaldo, quien la reconocerá cuando vea su espada. Éste, por tanto, en un primer momento se encuentra lejos de su hija para poder resolver su problema de honor. En un segundo momento, cuando la disfrazada se presenta ante él y le hace saber que Astolfo ha cometido contra ella un agravio, Clotaldo se presta a socorrerla creyendo que en realidad se trata de su hijo, pues desde el principio Rosaura aparece vestida de hombre. En un tercer momento, cuando la disfrazada le desvela su identidad, ya es tarde para que él pueda cumplir su promesa, pues su lealtad hacia Astolfo constituye un elemento primordial en su escala de valores, incluso por encima del honor de su hija. Hasta ese instante se han ido acumulando motivos para que Rosaura decida tomar la ini-

\footnotetext{
16 Esta línea de actuación de la disfrazada barroca fue señalada por Charles Vincent Aubrun al afirmar que «si está sola o se cree sola en el mundo, se disfraza de hombre $\mathrm{y}$, con ello, asume las prerrogativas de hombre; toma la espada y se marcha en busca de aquel que la engañó» (1968: 242).

17 Ésta es la visión positiva del honor de las dos que coexisten en Calderón, según Edward Honig. La negativa constituye una fuerza opresora y degradante, y la positiva permite al individuo preservar su propia identidad (1972: 5).
} 
ciativa y dirigirse al futuro rey, Segismundo, en busca de su solidaridad. Al mismo tiempo, ella le ofrece su ayuda en la consecución de la corona. De esta forma, como han señalado Edward M. Wilson (1976) y Enrique Rull (1980), entre otros, Rosaura es el instrumento de su conversión, pues Segismundo logra controlar sus pasiones y se propone la restauración del honor de Rosaura, lo que le conduce a convertirse en el perfecto príncipe al saber cumplir con su obligación. Ha sido la posición activa de Rosaura en la defensa de su honor la que ha propiciado la decisión de Segismundo, que se ve finalmente reafirmada por la recuperación de su condición nobiliaria. Se pone así de manifiesto la imposibilidad de compromiso que existía entre personas de distinto estamento social en aquella sociedad conservadora e inmovilista ${ }^{18}$.

Al igual que Rosaura y que Julia, la forma de expresar su feminismo reivindicador por parte de Ismenia en Los tres afectos de amor: piedad, desmayo y valor es la de erigirse en defensora de su propio honor, pero esta vez a través del disfraz de bandido. Ismenia ha sido rechazada por Libio, antiguo amante de ella que ahora pretende el amor de la princesa Rosarda. Cuenta con la complicidad de Anteo, quien también desea vengarse de la princesa por sus desprecios hacia él. Ismenia propone al caballero que dispare sobre aquella, pero en el último momento le falta valor $\mathrm{y}$ ha de hacerlo la dama vestida de hombre. Nuevamente nos hallamos ante un caso de soledad de la dama agraviada y, por tanto, de obligación de reparar por sí misma su perdido honor. Desde este punto de vista, el disfraz de Ismenia, en el afán por recuperar su honra y llevar a cabo su venganza, está justificado dentro del plano de la comedia. Pero, además, funciona también como mecanismo de crítica hacia el ilógico código de conducta que imponía la rígida idea del honor existente en aquella época. Esta vez Calderón se vale del recurso de la hipérbole ${ }^{19}$ vinculada al disfraz para presentar el tema de la reparación del honor a través de la sangre y expresar su repulsa hacia tal ideología. Como sabemos por documentos ${ }^{20}$ de la época, en la sociedad contemporánea al dramaturgo era relativamente frecuente la existencia de duelos y venganzas crueles que

\footnotetext{
18 Los documentos existentes sobre matrimonios y dotes muestran la enorme distancia que existía entre personas de distinto estamento social y, por ello, la imposibilidad de matrimonios mixtos. Véase, para este aspecto, Domínguez Ortiz, 1973a y J. M. Díez Borque, 1976, entre otros.

19 Este aspecto de la exageración deliberada de la realidad en el teatro de Calderón con fines de denuncia fue enfatizado, entre otros, por Thomas Austin O'Connor, 1983: 534.

20 Jerónimo de Barrionuevo [1654-1658], por ejemplo, recoge distintos casos, como el de un marido que intentó asesinar a su esposa por tres veces, «la primera con tósigo, la segunda con una noria, paseándose en ella como por una huerta, y la tercera ahogándola entre colchones» (Recogido en B.A.E., 1968: t. 222, 22).
} 
provocaban la muerte por causa de una ofensa de honor. Existía una legislación que permitía la venganza del honor a través de la sangre, aunque según parece, los testimonios recogidos ${ }^{21}$ demuestran la existencia mayoritaria de soluciones menos violentas y la minoritaria de la opción sangrienta. Ismenia trata de resolver mediante la sangre algo que no encontrará satisfacción por esta vía. Por supuesto que las ofensas del honor requerían una reparación e incluso Calderón, mediante el disfraz, propugna la restauración del mismo por parte de la propia mujer, pero no a través de la violencia y la sangre. Finalmente, Ismenia es perdonada por Rosarda, pues el disparo en realidad no ha recaído sobre ella sino sobre su caballo, pero no logra recuperar el cariño de su antiguo amante, quien termina prometiéndose a la princesa.

En el auto El gran mercado del mundo, La Culpa se siente traicionada, pues ha sido abandonada por el Buen y el Mal Genio. Ante lo que ella considera una grave ofensa, toma la decisión de convertirse en vengadora de la misma y trata de recuperar el cariño de los dos galanes antes de que puedan conquistar a la bella y dulce dama llamada Gracia. El mecanismo empleado es el múltiple disfraz. Su discurso desgarrado y reivindicador de venganza bien podría ser aplicado a la dama abandonada de una comedia:

$\begin{array}{ll}\text { CULPA. } & \text { Los galanes de este valle } \\ \text { de lágrimas, que solían } \\ \text { darme adoración, me dejan } \\ \text { despreciada y ofendida... } \\ \text { Yo soy Piedra ( } \text { el mundo tiemble!); } \\ \text { a urdir voy ( } \text { el cielo gima!) } \\ \text { malas costumbres ( } \text { ¡mortales!); } \\ \text { rayos mis enojos vibran, } \\ \text { fuego mis labios arrojan, } \\ \text { llamas mis voces fulminan; } \\ \text { temblad, temblad de mis rabias; } \\ \text { temed, temed de mis iras. }\end{array}$

(T. III, 229 y 230) ${ }^{22}$

Salvando las distancias producidas por el distinto asunto que trata el auto con respecto a la comedia o a la pieza breve, es decir, la Eucaristía,

\footnotetext{
21 Véase, sobre todo, Américo Castro, 1916; Menéndez Pidal, 1937 y J. A. Maravall, 1979. A. Domínguez Ortiz insiste en que los disensos conyugales, en general, no llegaban a la sangre, sino que se solucionaban con separaciones de hecho. Pero lo que sí sucedía en algunos casos era el encierro de la mujer en un convento, en una galera o en una cárcel de mujeres (1992: 303).

22 De aquí en adelante para los autos sacramentales citaremos por Valbuena Prat, 1991, consignando tomo III y página. Para las comedias, por Valbuena Briones, 1987, señalando tomo I, jornada y página. Para los dramas, por Valbuena Briones, 1991, mediante tomo II, jornada y página. Para las piezas breves, por Evangelina Rodríguez y Antonio Tordera, 1982, con página y versos.
} 
la Culpa, como ser femenino, actúa movida por el sentimiento de abandono y desprecio. Recordemos las palabras procedentes de Julia en La devoción de la cruz y podremos establecer un cierto paralelismo entre ellas. Nos referimos a la escena en que es abandonada por Eusebio en las tapias del convento y le es imposible regresar a causa de la desaparición de la escalera que le permitió salir del mismo. Sus palabras, como las de la Culpa, se hallan caracterizadas por el dolor y el dramatismo:

$\begin{array}{ll}\text { JULIA. } & \text { Pues si ya me habéis negado } \\ \text { vuestra clemencia, mis hechos } \\ \text { de mujer desesperada } \\ \text { darán asombros al cielo, } \\ \text { darán espantos al mundo, } \\ \text { admiración a los tiempos, } \\ \text { horror al mismo pecado } \\ \text { y terror al mismo infierno. }\end{array}$

(T. II, II, 409)

Ambas son percibidas como mujeres desdeñadas que planean su venganza contra aquel que provocó su personal drama. Se disfrazan para no ser reconocidas y deciden convertirse en defensoras de su propio honor sin contar para ello con la ayuda de ningún hombre. Los signos auditivos y visuales que el público recibe desde el escenario le comunican la idea de dos mujeres que renuncian al sometimiento o a la resignación, que no se conforman con ser las víctimas inocentes del desprecio y el abandono. También se hallan presentes, claro está, las convenciones dramáticas que le proporcionan al dramaturgo una determinada utilidad histriónica por la intensidad de las emociones transmitidas y por el arrebato que provocan en el espectador. La ideología transmitida, por tanto, mediante la adopción de los disfraces de la Culpa, no varía, en este sentido, con respecto a las otras disfrazadas, pues además del mensaje religioso, también se hallan presentes algunas de las estructuras, motivos y reivindicaciones femeninas de la comedia.

1.2. A través del empleo de determinados disfraces, el feminismo reivindicador adopta la forma de exhortación a una actitud capaz de introducirse en ámbitos reservados en exclusiva para el sector masculino. Así, Julia, la disfrazada de La devoción de la cruz, utiliza la vestimenta varonil no sólo para defender su propio honor, sino como instrumento imprescindible para convertirse en líder de los bandoleros capitaneados hasta entonces por Eusebio. Es valiente y audaz. Hace gala de un ánimo y de una fortaleza de espíritu que conduce a la banda a reagruparse y a repetir su ataque con renovado entusiasmo. $Y$ es que en realidad Julia no transforma su personalidad en sentido estricto, sino que 
esas cualidades consideradas tradicionalmente como parte integrante de la conducta masculina, ya conformaban su idiosincrasia femenina antes de vestirse con el disfraz varonil. Mediante éste pudo mostrar al mundo lo que una mujer decidida es capaz de hacer. La adopción de la nueva identidad le permite poner de manifiesto unas cualidades tradicionalmente consideradas positivas sólo si se hallaban en la personalidad de un hombre.

En El castillo de Lindabridis Claridiana se introduce en el ambiente masculino de los torneos caballerescos para ganar la mano de una dama a la que pretende apartar de su amado Febo. Bajo su disfraz varonil es capaz de enfrentarse tanto al caballero del Febo como al Fauno, que ha vencido previamente al resto de los caballeros que se han enfrentado con él. Así pues, el campo de torneo donde Claridiana se erige con la victoria sobre el personaje semimitológico, adquiere un significado simbólico más allá del puramente novelesco y ambiental, pues se convierte en espacio escénico-simbólico ${ }^{23}$ del triunfo femenino. El disfraz varonil permite la aceptación de esas conductas masculinas en una mujer, pues dentro del universo ilusorio de la comedia los demás personajes la consideran un hombre. Desde esta perspectiva, el travestismo actúa como mecanismo tranquilizador de la conciencia subliminal del espectador, que se halla inmerso en una sociedad profundamente patriarcal y que consiente la promoción femenina y su intrusión en un campo de actuación masculino debido a que la auténtica identidad de la impostora permanece oculta tras el seudónimo varonil.

Claridiana, como prototipo de mujer segura de sí misma y de sus propias posibilidades de éxito, simboliza la actitud que la mujer barroca debía erigir para escapar de las convenciones sociales que actuaban como una rémora y adentrarse en el universo patriarcal con claridad de ideas y con gran firmeza. Sólo esta postura permitiría que el colectivo femenino consiguiera el triunfo de sus reivindicaciones.

En la comedia Hado y divisa de Leonido y Marfisa, ésta se infiltra, también mediante la adopción del atuendo varonil, en un espacio no menos expuesto y arriesgado que las anteriores: el campo de duelo entre caballeros. En todos los casos se produce lo que M. ${ }^{a}$ Josefa Porro ha denominado muy acertadamente «la ruptura de fronteras» (1995: 155), a través de la combinación y superposición de disfraz y conducta masculina. La actitud combativa de Marfisa en el duelo haciéndose pasar por Leónido - a quien cree muerto- contra el fingido soldado, constituye una metáfora de la lucha de la mujer por sus ideales.

23 La condición simbólica del espacio, así como de los objetos y personajes que aparecen en el escenario fue puesta de manifiesto por los teoristas rusos y checos de los años treinta y cuarenta. Véase este aspecto en relación con la obra de Calderón en José Amezcua, 1983 y Melveena McKendrick, 1991: 130. 
1.3. A partir de la conducta de algunas disfrazadas se manifiesta la exhortación a una actitud capaz de enfrentarse a la autoridad masculina. En el caso de Julia de La devoción de la cruz se halla representada por Curcio, su padre. Ya en el plano de la comedia, Julia había intentado sublevarse contra su decisión de hacerla ingresar en un convento. Éste constituía una solución al conflicto de honor causado por las relaciones ilícitas entre su hija y un hombre desigual a ella en el aspecto de la jerarquía social. Sin embargo, finalmente accede a obedecer las órdenes de su padre debido al descubrimiento del asesinato de su hermano Lisardo a manos de su amante Eusebio. Más tarde, cuando Julia se disfraza varonilmente y se convierte en líder del grupo de bandoleros, se propone el enfrentamiento con su padre y sus partidarios, no ya mediante el empleo de fórmulas verbales como anteriormente había hecho, sino desde la lucha armada. Desde esta perspectiva, Julia representa la exhortación a la negativa de las mujeres frente al autoritarismo masculino. Su ansia de libertad ha sido interpretada por Antonio Regalado como un antecedente de los derechos garantizados por las constituciones políticas modernas (1995, II: 405 y 406). Por otra parte, la constante de la rebelión contra la autocracia del padre ha sido vista por algunos autores como reproducción de un episodio autobiográfico del dramaturgo ${ }^{24}$.

En esta tragedia se plantea la solución del convento como salida a un agravio de honor que no tiene arreglo a través del matrimonio. El pretendiente es dueño de una fabulosa hacienda, pero es de linaje desconocido. Este caso no constituía un hecho aislado, ya que el convento ${ }^{25}$ representaba la solución para determinadas dificultades económicas o relacionadas con el honor. Lo reseñable viene a ser la falta de libertad de las mujeres para decidir sobre su propio destino mientras que la autoridad masculina, personificada en el padre o en el hermano, asumía toda responsabilidad en este sentido, pues la mujer era considerada como un objeto más de la propiedad varonil ${ }^{26}$. Julia no duda en enfrentarse a la autoridad paterna desde

24 Parece admitido que Calderón en su adolescencia fue testigo del excesivo rigor que su padre ejerció contra sus dos hermanos varones. De ahí la recurrente figura del padre autoritario en sus obras. Véase Antonio Regalado, 1995, t. II, 433; Sidney F. Wexler, 1966: 19 y Ángel Valbuena Prat, 1970, XXIX.

25 Para ampliación de este aspecto del convento como refugio de mujeres y como solución de problemas familiares, véase, por ejemplo, Deleito y Piñuela, 1952; J. Imirizaldu, 1977; Julio Caro Baroja, 1978; Marcellin Defourneaux, 1983; López Cordón, 1984; Sánchez Ortega, 1984; Mariló Vigil, 1986; Gil Ambrona, 1987; J. L. Sánchez Lora, 1988; Néstor Luján, 1988; Antonio Domínguez Ortiz, 1992; Margaret L. King, 1993; Cristina Segura Graíno, 1996 y Margarita Ortega López, 1997.

${ }_{26}$ Es ampliamente conocida la legitimación de la apropiación física de las esposas por sus maridos basándose en el código del honor, pues se consideraba que la mujer transmitía la sangre hidalga o plebeya. Véase, por ejemplo, A. Domínguez Ortiz, 1992: 307. 
dos ámbitos diferentes: dentro del plano de la comedia mediante el diálogo; dentro del plano de la ficción mediante el disfraz varonil y las armas propias del universo masculino: la lucha y el enfrentamiento físico. Éste no llega a producirse, pues de regreso al plano de la comedia, Julia descubre la muerte de Eusebio y su parentesco con él y se arrepiente de todas sus acciones criminales. La actitud final de Curcio, quien permanece en el tablado amenazando de muerte a su hija, revela la solución que la autoridad masculina pretende otorgar al conflicto. La santificación de la disfrazada mediante su ascensión a los cielos pone de manifiesto el desacuerdo con los modos violentos e intolerantes de la imposición masculina sobre la existencia de las mujeres.

En El monstruo de los jardines, el disfraz de Aquiles conduce a Deidamia a una transformación de su conducta con respecto a la autoridad paterna ${ }^{27}$. En un principio asistimos a la presentación en escena de una dama que, por respeto y obediencia a su padre, el rey de Egnido, acepta el matrimonio con Lidoro a pesar de que no le ama y ni siquiera le conoce:

DEIDAMIA. Tanto el sentimiento fue
de dar, a quien nunca vi,
mi padre mi libertad,
que ofendida la crueldad
de mi altivo pensamiento
se ha hecho aborrecimiento
lo que aún no fue voluntad.

(T. II, II, 2007)

Mediante la queja de Deidamia se refleja lo que era una costumbre extendida en la época contemporánea al dramaturgo: acordar un matrimonio sin la aquiescencia previa de la mujer interesada ${ }^{28}$. De esta manera, el matrimonio, que era percibido generalmente por las féminas como una liberación ${ }^{29}$, se convertía en una simple transacción comercial y en una forma de sometimiento contraria a su voluntad. $\mathrm{Y}$ así era la realidad social en un momento en que los compromisos matrimoniales se solían basar en el aspecto económico más que en el amoroso. El matrimonio se entendía como un negocio rentable que cooperaba, a la vez, en el encuentro de una

\footnotetext{
27 Esta transformación de su actitud hacia el padre fue apuntada por Alexander A. Parker, 1.986.

28 Acerca del matrimonio impuesto véase Deleito y Piñuela, 1966; Domínguez Ortiz, 1973b y 1992; Mariló Vigil, 1986; J. A. Maravall, 1978; François Delpech, 1979; Marcellin Defourneaux, 1983; Paloma Cepeda, 1986; Carmen M. ${ }^{a}$ Cremades Griñán, 1986; J. M. Díez Borque, 1990; Isabel Pérez Molina, 1994; Ludwig Pfandl, 1994 y Margarita Ortega López, 1997, entre otros.

${ }_{29}$ Recordemos, como señaló por ejemplo Mariló Vigil, que «una de las cosas que más deseaban las mujeres, aparte de ser hermosas era casarse» (1986: 78).
} 
vida apropiada para una mujer decente y en el incremento de la fortuna personal del cabeza de familia. La dote era el elemento fundamental de la cuestión y de ella dependía realmente la posibilidad de casarse.

Al final de la obra, Deidamia, por causa del amor hacia Aquiles, renuncia a la obediencia, a Lidoro y a su propio honor:

\section{DEIDAMIA. Pierdo el vivir si te pierdo. \\ No te ausentes, no me dejes conmigo a mí, y yo te ofrezco ser tuya, aunque se aventuren padre, esposo, honor y reino. Tuya he de ser: no te vayas.}

(T. II, III, 2020)

Gracias a la revelación de la verdadera historia del disfrazado Aquiles y a la actitud firme de Deidamia, ésta consigue finalmente casarse con el hombre a quien ama. Calderón reivindica, así, el derecho de la mujer a no aceptar dicha imposición masculina.

1.4. La reivindicación de un mayor protagonismo femenino en la lucha social, la realiza Calderón a través de la metáfora del cambio de espacio por parte de la disfrazada. El abandono del encierro monástico por parte de Julia (La devoción de la cruz) simboliza la salida de la mujer hacia el reencuentro activo con su propio destino, que ya estaba cuajando en las mujeres más progresistas de la sociedad barroca. Estas muestras de inquietud, como ya hemos mencionado, fueron descalificadas por los más severos moralistas. A pesar de ello, las mujeres no se conformaron con un papel pasivo y manso. Ésa es una imagen parcial que ha llegado hasta nosotros a través de la visión subjetiva de algunos sectores de la historia social, pero que no corresponde a la totalidad femenina, si bien era una minoría la que llevaba sus inquietudes de forma efectiva al campo de lo concreto y real y una mayoría la que permanecía estancada en el campo de la utopía por la imposibilidad de medios ${ }^{30}$. Por ello se propugna, mediante el simbolismo del viaje de la disfrazada, la salida de la mujer de su propia inmovilidad hacia un mundo más amplio y hacia una postura mucho más activa en sus reivindicaciones sociales. En La devoción de la cruz

30 Algunos estudios han hecho hincapié en la existencia de mujeres desenvueltas y menos enclaustradas de lo que los sectores más conservadores quisieron permitir y transmitir. Véase, en este sentido, Mariló Vigil, 1986: 24 y Margarita Ortega López, 1997: 280-284, entre otros. En el lado opuesto se hallan los que consideran que la mujer estaba sometida a una tan estrecha vigilancia que apenas tenía contacto con el exterior. Sólo la aventurera o la aristócrata podían gozar de una cierta libertad superior a las demás. Véase, para esta postura, por ejemplo, J. Reglá, 1971: 230; Melveena McKendrick, 1974: 35 y Marcellin Defourneaux, 1983: 144. 
Julia toma la decisión casi sacrílega, desde la mirada conservadora de aquellos tiempos, de abandonar el convento en el que había permanecido hasta entonces, no por una total convicción, sino por un desengaño amoroso que de paso solucionaba un conflicto familiar. Pero es preciso señalar que el travestismo de Julia no tiene lugar de forma previa a su alejamiento del convento, sino de manera posterior al mismo. Julia forma parte de ese grupo de personajes femeninos calderonianos novedosos y transgresores que no precisan el atuendo varonil para escapar del ambiente opresor en que se hallan recluidas. Traspasa las fronteras conventuales ataviada con un hábito. El recurso empleado para presentar esta decisión subversiva es el tema del amor y la desesperación por el abandono de Eusebio. Calderón hace uso de convenciones que cuentan con el agrado del público para presentar la transgresión. Parte de situaciones conectadas con la vida real - recordemos el convento como aparcamiento de mujeres- que permiten una más fácil comprensión por parte del espectador barroco.

En La vida es sueño Rosaura abandona su hogar en Moscovia para dirigirse a Polonia en busca de su olvidadizo amante, Astolfo, y de su padre, Clotaldo. Él es el único que puede devolverle la identidad nobiliaria necesaria para poder contraer matrimonio. Rosaura no sólo ha tomado la decisión de abandonar su entorno doméstico y su región, sino que deja su propio país y se introduce en otro superando el temor a lo desconocido, consciente de que ha de luchar por la consecución de sus objetivos. En esta ocasión, Rosaura no escapa de su hogar a escondidas, sino alentada por su madre, Violante, quien ha sufrido anteriormente el mismo desengaño que ahora padece su hija. Mediante este recurso se refleja la comprensión y el apoyo de una mujer hacia otra y el espíritu de lucha presente en muchas de ellas provocado por el padecimiento de una misma situación de humillación femenina frente a la autocracia masculina. El viaje de Rosaura simboliza la salida de la mujer de un mundo cerrado y asfixiante predestinado a la resignación y diseñado desde una mentalidad conservadora y preminentemente masculina hacia una vida en que ella tome sus propias iniciativas y decisiones y en la que pueda luchar contra la humillación y la pasividad a que está condenado el sector femenino. Las dificultades que encuentre en el camino de esa lucha por sus ideales no deben ser obstáculos que la paralicen, sino resortes que la empujen a seguir trabajando por una sociedad más justa e igualitaria para con las mujeres. Lo más cómodo era permanecer dentro del ámbito doméstico a salvo de riesgos, obedecer las reglas de un código mayoritariamente masculino y no correr riesgos. Sin embargo, también empezaban a pulular, entre la mentalidad del aquel momento, mujeres atrevidas que hacían gala de una férrea voluntad, capaces de trasladar a la realidad sus utopías sociales. La pugna femenina por la libertad de movimientos fue ardua pero tenaz. Poco a poco, la mujer comienza a apartarse de las labores típicamente femeninas en que al sector 
masculino le convenía tenerla entretenida y controlada, y comienza a avanzar pertrechada con su ingenio y su tenacidad. Calderón presenta esta idea dentro del espacio ficticio del travestismo, que en esta obra es predominante, y ve incrementado su aspecto dramático a través del recurso de la multiplicidad de disfraces y la dualidad sexual de Rosaura. Por otra parte, el dramaturgo también utiliza ciertos recursos para granjearse el apoyo del público masculino. Emplea la imagen de la joven ante el rey como una mujer frágil y desvalida, necesitada de asistencia masculina para poder llevar a cabo la resolución de su plan. Así como en la obra Rosaura es consciente del afán de prepotencia masculina y se muestra sumisa para conseguir la empatía de Segismundo, Calderón emplea esta misma arma para granjearse la comprensión del espectador y tener así la oportunidad de poder presentar el tema de la mujer mediante una convención literaria que tenía el éxito asegurado. La mentalidad abierta y flexible de la disfrazada, su actitud firme y segura representan la exhortación a las mujeres de su época a la lucha por la consecución de sus ideales como mujeres y como personas dentro de una sociedad marcadamente conservadora.

En Las manos blancas no ofenden César y Lisarda se disfrazan con atuendos del sexo opuesto y abandonan su hogar guiados por idéntico móvil: conseguir el amor de la persona amada. César, a pesar de su, en apariencia, ventajosa condición masculina, encuentra grandes obstáculos en su autoritaria madre para llevar a cabo sus proyectos amorosos. Por ello recurre al disfraz femenino. Lisarda ha sido criada por su padre en un ambiente ciertamente varonil. Se encontraba bajo la tutela de su tío Filiberto, pero éste ha muerto y ella se halla libre para adoptar la decisión que más le convenga. En el plano de la comedia, por tanto, hallamos los elementos justificativos de las acciones de los dos. Pero además existe una diferencia añadida entre ambos que conecta con las reglas del convencionalismo social: Lisarda es encontrada casualmente por su padre cuando éste trata de hallar a su sobrino César en la corte de la princesa Serafina y a partir de entonces se muestra vigilante de su honor; César, como hombre, es el único responsable de todos sus actos. Su madre ${ }^{31}$ no vuelve a tener cabida en ningún momento en el desarrollo de la acción. Calderón propugna ciertamente un mayor protagonismo femenino en la lucha social de las mujeres, pero no rompe con los esquemas ni con las reglas del juego social. Son precisamente éstas las que le permiten adentrarse en un nuevo nivel de reivindicaciones. Así accede a la presentación de un tema censurable por lo revolucionario en aquellos tiempos. El público disfrutaba observando sobre el tablado la transgresión, pero optaba mayoritariamente por retomar

31 Como es bien sabido, la madre es un personaje femenino casi ausente, no sólo en ésta, sino, en general, en toda la comedia del Siglo de Oro. Véase para este aspecto, por ejemplo, el trabajo de Christiane Faliu-Lacourt, 1979. 
su realidad cotidiana desde la tranquilidad y comodidad de las sólidas convenciones sociales. Alexander A. Parker afirmó a este respecto que, «ya sean cómicas o serias, estas obras indican los límites que la España del siglo XVII imponía al feminismo: se podía permitir con buen humor que las mujeres superaran en ingenio a sus padres y hermanos, pero no se les permitía rebelarse contra su propia naturaleza» (1991: 180). Sin embargo, como venimos observando, la esencia de las actuaciones de muchas de las disfrazadas se mueve, no sólo en los parámetros de las convenciones dramáticas, que también es cierto, sino además en los de la reivindicación social. Ésta existió ciertamente en el teatro de Calderón.

En El castillo de Lindabridis ésta abandona su castillo para ir en busca de Claridiano. Pero lo lleva a cabo disfrazada de hombre para no ser reconocida. Esta acción simboliza la adopción de una postura activa para reencontrarse con su propio destino y el abandono de su pasividad como mujer sumisa y paciente. En la comedia se refleja este aspecto mediante la recreación del ambiente caballeresco. Como dama instalada en una corte de tales características, se supone que ha de aguardar resignadamente a ser ganada como esposa por el caballero andante más valiente y audaz. Ella, sin embargo, rompiendo con los moldes estereotipados que se esperan para una persona de su condición y sexo, se decide a convertirse en protagonista activa de sus propios deseos y a encaminarse hacia ellos mediante sus personales acciones. En un arrebato apasionado, Lindabridis decide confiar en sí misma:

LINDABRIDIS. $\quad \mathrm{Y}$ yo a tu lado quiero acreditar este valiente acero, que no le ceñí en vano; y ganándome a mí mi propia mano, darme yo a mi albedrío.

(T. I, III, 2091)

Su castillo constituye un lugar seguro y cómodo, pero también una forma de mantenerla apartada del mundo exterior y real. Para luchar por sus ideales se atreve a dar el paso de su abandono.

Al igual que Lindabridis, Claridiana ha dejado su entorno habitual para ir en busca de su amado, el caballero del Febo, pero en esta ocasión ha marchado de su patria. Finalmente, Claridiana conseguirá su objetivo gracias a su inconformidad con las reglas sociales. Ha abandonado su país y ha luchado con otros hombres haciendo caso omiso de las normas que regían la conducta estereotipada de las mujeres de su época, aunque eso sí, enfundada en un traje varonil, pues es inteligente y no ignora que existen ciertos ámbitos a los que una mujer simplemente por serlo no puede acceder. Por otra parte, su comportamiento transgresor ha sido presentado 
ante el público barroco mediante un trasfondo escenográfico lúdico y espectacular, que proporciona a sus acciones un halo de marcado histrionismo y ficción imprescindible para la presentación ideológica de la reivindicación femenina. A través de la actitud simbólica llevada a cabo por las disfrazadas de esta comedia, el dramaturgo alienta a la ruptura de fronteras no sólo físicas sino psicológicas: la fuerza y la determinación son capaces de colaborar con la mujer poseedora de las mismas para abandonar las rémoras que la encadenan cada día a su estancamiento social y personal. El objetivo amoroso de ambas disfrazadas de esta comedia, Claridiana y Lindabridis, constituye el tópico empleado por el dramaturgo para acercar la comedia al público, pues el tema del amor ${ }^{32}$ contaba con el total beneplácito del mismo. El mismo empeño y ardor que un gran número de mujeres mantenía hacia las maneras estereotipadas y externas del amor cortesano, era preciso también manifestar con respecto a los deseos de algunas de ellas -aunque cada vez constituían un grupo más numerosode avanzar por la senda del igualitarismo social y cultural. De hecho, Claridiana se nos presenta como mujer de inquietudes intelectuales y no sólo amorosas:

Claridiana.
Aue soy desdichada temo.
(es verdad yo lo confieso)
a Febo en esta aventura,
porque en ciencias y armas tengo
experiencia y noticias
con que aventurarme puedo
a salir con la victoria.

(T. I, I, 2064)

A pesar del natural temor ante el reto al que se va a enfrentar, Claridiana se arma de valor y de fe en sí misma y lucha, no sólo contra el caballero del Febo, sino también contra el propio Fauno. Lo que no han logrado los demás caballeros andantes, lo consigue ella mediante su actitud de mujer entusiasta y comprometida con su objetivo, pues finalmente llega a vencerlo. Como ella, la mujer barroca se empeñaba cada vez de forma más habitual en su formación personal y cultural, acudía a academias literarias

32 Ya conocemos el interés que el tema del amor despertaba en las mujeres barrocas y sus grandes deseos de ser amadas dentro del los esquemas del estereotipo caballeresco y cortés. Acerca de estas formas de seducción y galanteo véase, entre la amplia bibliografía, la siguiente: Díaz Plaja, 1963; Deleito y Piñuela, 1966; Otis H. Green, 1969, I; Claire Pailler, 1974; Cesáreo Bandera, 1982; José Antonio Pérez Rioja, 1983; Marcellin Defourneaux, 1983; Mary Gaylord Randel, 1983; Sánchez Ortega, 1984; Alexander A. Parker, 1986; Mariló Vigil, 1986; Pedro M. Cátedra, 1989; M. ${ }^{a}$ Pilar González Velasco, 1989; Everett Hesse, 1989; Rina Walthaus, 1993; José Luis Canet, 1995; Elena Real Ramos, 1995; M. ${ }^{a}$ Josefa Porro, 1995 y Alicia López de José, 1997, entre otros. 
e incluso las fundaba y manifestaba inquietud en campos situados más allá de los intereses que se suponían propios de su sexo en aquella época. Pues bien, haciendo referencia a ese rasgo emprendedor presente en el espíritu femenino barroco, se las exhortaba a salir de su pretendida pasividad y de su fomentado silencio para tratar de lograr la victoria, aunque fuera de forma paulatina, en el campo de los reclamos femeninos.

En Hado y divisa de Leonido y Marfisa la disfrazada abandona la gruta en que ha vivido y ha sido criada por su padre adoptivo, Argante, para salir a conocer el mundo real y a defender el honor de Leonido. Ella misma denomina prisión a aquel lugar en donde ha permanecido desde su nacimiento:

$\begin{array}{ll}\text { MARFISA. } & \text { ¿No puedo yo en su ausencia } \\ & \text { sus estudios abrir, } \\ & \text { quebrarle sus cristales, } \\ & \text { romper y destruir } \\ & \text { cuadrantes y astrolabios, } \\ \text { porque restituir } & \text { no pueda a su prisión } \\ \text { mi libertad...? }\end{array}$

Una vez más nos hallamos ante el simbolismo de la prisión que para la mujer barroca representaban, en general, su vida y hogar cotidianos ${ }^{33}$. Efectivamente, en el soliloquio de Marfisa se hallan contrapuestas dos palabras claves en la vida femenina de aquella sociedad reaccionaria: la «prisión» representada por la gruta y símbolo de la falta de actividad y de autonomía de la mujer del siglo XVII y la «libertad» anhelada y plasmada en la comedia mediante el abandono de la cueva y la búsqueda personal de sus propios proyectos.

En El José de las mujeres la intelectual Eugenia ${ }^{34}$ abandona el hogar

33 En este sentido, M. ${ }^{a}$ Josefa Porro señala la diferencia entre una vida constreñida a los espacios interiores, en que existe un sometimiento a las reglas preestablecidas, y el espacio público, escenario de la transgresión y reducto de la marginación (1995: 155).

${ }_{34}$ Ya anteriormente María Santomauro constató el hallazgo de Calderón al adivinar en ella a la mujer del siglo XX, que rechaza ocuparse sólo de quehaceres domésticos y opta por dedicarse al estudio (1985: 18). Acerca de la formación que recibían en realidad las mujeres del Barroco, véase Néstor Luján, quien incide en su deficiencia (1988: 309); Sonja Herpoel se centra en la amenaza de la Inquisición sobre la mujer intelectual (1989: 123-131); M. ${ }^{a}$ Gloria Ródenas y Susana M. ${ }^{a}$ Vicent insisten en la idea de los conventos como lugares casi exclusivos de formación intelectual para las mujeres (1992: 93); M. ${ }^{a}$ Josefa Porro considera a la mujer desde la perspectiva de sujeto de la actividad literaria (1995); Cristina Segura habla de un retroceso en la producción escritora de la mujer y del recorte de libertades para el sector femenino (1996: 39 y 40); Margarita Ortega apunta los deseos existentes en toda Europa de reformar la educación que recibían las mujeres (1997: 289-295). 
paterno disfrazada de hombre. Su situación la ha forzado a tomar esta drástica solución. Son varios los factores que la han conducido a ello. El dramaturgo los presenta dentro del plano de la comedia como elementos justificativos de su conducta: su afán de profundizar en el conocimiento de la fe cristiana y la soledad e incomprensión por parte de su padre Filipo. Éste piensa que ha perdido la razón, la encierra y quema sus libros y papeles. En realidad existe toda una ideología plasmada mediante el uso de la simbología y reflejada en la obra mediante esos motivos mencionados: el religioso, desde la perspectiva del disfraz, representa la búsqueda de los ideales que persigue Eugenia como mujer y como persona con derecho al libre albedrío ${ }^{35}$; la actitud paterna es el reflejo de la falta de libertad femenina y de comprensión hacia sus necesidades y sentimientos:

EUGENIA.
Esto, pues, por una parte,
por otra, el ver que me tengan
por loca, y que como a tal
mi padre me encierre y prenda,
quemándome cuantas tablas
libros y papeles eran
mis familiares amigos,
me ha puesto osada y resuelta
en obligación de que
haga de todos ausencia...

(T. II, II, 921)

Eugenia representa la realidad de muchas mujeres que pasaban su vida sometidas bajo el yugo de un padre o un hermano autoritarios que coartaban su libertad y que impedían su desarrollo como mujer y como ser humano.

En los autos El gran mercado del mundo y La protestación de la fe las disfrazadas respectivas, Culpa y Herejía, emprenden también un largo viaje para lograr sus objetivos. La Culpa adopta varios disfraces y acude al mercado del mundo tras el Buen y el Mal Genio para tratar de recuperar su cariño, aunque éstos, a su vez, intentan hacer méritos para conquistar a una dama llamada Gracia. Por su parte, la Herejía en La protestación de la fe decide vestirse de peregrino - que pone de manifiesto también el carácter viajero de la disfrazada - y acudir tras la reina Cristina de Suecia. Ésta ha sido invitada a un banquete ofrecido por la Sabiduría. La Herejía

35 Antonio Regalado ha analizado el factor teológico en relación con el papel de la mujer en el teatro barroco, pues al asumir algunos dramaturgos la cuestión del libre albedrío no excluyeron al personaje femenino de tal problemática. Según él, el hecho de que la mujer participe en actividades supuestamente masculinas, adopte papeles de hombre y se enfrente con cuestiones filosóficas y teológicas, supone algo más que un mero gusto o afán de novedades. De ahí que ser cristiano o el compromiso de serlo trascienda la dualidad sexual (1995, I: 935-939). 
planeará introducirse en el mismo sin ser reconocida para poder satisfacer su ira mediante la venganza, pues intentará profanar la Sagrada Mesa. El riesgo de ser descubierta existe, pero ella no se intimida. Su actitud, dejando de lado toda cuestión temática relacionada directamente con el asunto del auto como tal, es la de una mujer firme, resoluta y valiente que no teme los riesgos y que decide abandonar su entorno doméstico para adentrarse en un país desconocido, España, en donde es extranjera.

La llave de la solución, según el enfoque del dramaturgo tanto en autos como en comedias, la tiene la propia mujer mediante su actitud resoluta, audaz y en absoluto timorata. El hogar simboliza, una vez más, la prisión de las mujeres contemporáneas a Calderón. Su abandono es la metáfora de la libertad de movimientos reivindicada y de su resolución a dejar la situación cómoda que suponía la protección masculina. A cambio, debían correr determinados riesgos que podían conducirlas a ser protagonistas activas de su propia vida y a no permitir que fuera un hombre quien decidiera sus ideales y su forma de vivir.

En Los tres afectos de amor: piedad, desmayo y valor, Ismenia, como los demás personajes anteriores, abandona su hogar para ir en busca de su antiguo amante, Libio. Pero en esta ocasión, Calderón no se vale del disfraz varonil para presentar en escena tal acción, aunque sí se emplea el disfraz de personalidad, pues Ismenia se hace pasar por una dama distinta de sí misma e incluso adquiere un falso nombre: Astrea. Mediante el personaje y la acción de mujeres como Ismenia nuestro dramaturgo da un paso adelante, pues ya no se trata de ocultar una conducta transgresora tras la apariencia ficticia de un varón, sino que es la propia mujer la que comete tal acto subversivo -en este caso, el abandono del entorno doméstico-, aunque eso sí, inserto en otro universo de ficción que permite nuevamente la presentación de ideas novedosas desde el plano de lo irreal y fabuloso. El intento de asesinato como defensa de su honor, sin embargo, se produce ya dentro plenamente de la identidad varonil de Ismenia ${ }^{36}$. La metáfora del viaje, por tanto, adquiere en este drama connotaciones algo distintas. Existe paralelismo en el significado de la misma -escape de un ámbito asfixiante-, pero difiere en el significante empleado, pues se ha sustituido el travestismo por un disfraz de personalidad. Sin embargo, el dramaturgo ha empleado para su presentación determinadas convenciones dramáticas coincidentes también con las otras obras anteriores: el tema del amor y la venganza como medio de restaurar el honor perdido por una mujer.

1.5. Presentación de la mujer como ser humano completo. En $L a$ vida es sueño, Calderón utiliza para poder presentar ante el público barro-

36 Sobre este aspecto, véase el apartado dedicado a esta obra en el epígrafe 1.1 de este trabajo. 
co esta idea, el recurso de la dualidad sexual de la disfrazada. Rosaura aparece vestida de hombre en la primera jornada con el objetivo de restaurar su honor; de dama de la infanta Estrella en la segunda jornada con la finalidad de vigilar a Astolfo y de estorbar su amor con Estrella; de mujer y hombre a la vez, caracterizada con rasgos humanos masculinos y femeninos - de acuerdo con el estereotipo de la época-, para poder llevar a cabo acciones propias tanto de un sexo como del otro.

Mediante la presentación de un recurso caracterizado por su sorprendente imaginación y marcado histrionismo, Calderón no sólo logra provocar la admiración del público, sino también expresar la reivindicación de la consideración completa y no parcial de la mujer. Rosaura es capaz, como mujer, de realizar acciones pertenecientes al campo de actuación femenino, pero también puede tomar las riendas de su propio destino y adoptar decisiones que entonces se consideraban más propias de hombres que de mujeres. Rosaura no se comporta como la generalidad femenina de la época, pero sus actuaciones conectan con las fantasías de muchas féminas asistentes a la representación. En cuanto al público masculino, éste no podía sentirse ofendido, pues la apariencia empleada para la reivindicación femenina había sido el disfraz y la ambigüedad sexual. El siguiente parlamento de Rosaura manifiesta ideología, pero también constituye una estratagema del dramaturgo para agradar al público masculino:

ROSAURA. Mujer, vengo a persuadirte
al remedio de mi honra,
y varón, vengo a alentarte
a que cobres tu corona.
Mujer, vengo a enternecerte
cuando a tus plantas me ponga,
y varón, vengo a servirte
cuando a tus gentes socorra...
Y así, piensa que si hoy
como mujer me enamoras,
como varón te daré
la muerte en defensa honrosa
de mi honor, porque he de ser,
en su conquista amorosa,
mujer para darte quejas,
varón para ganar honras.

(T. II, III, 529 y 530)

La clarividencia y sensibilidad del dramaturgo reside, sin embargo, en que es una mujer, Rosaura, la que es capaz de poner de manifiesto ambos tipos de actitudes, pues es considerada como un ser completo y diverso ${ }^{37}$

37 Antonio Regalado ha hecho hincapié en la variedad del personaje femenino calderoniano, pues se apartó del tópico y abarcó muchos más matices y posibilidades que el de sus predecesores y contemporáneos. Ternura, delicadeza, fortaleza y resolución se pueden hallar simultáneamente en un mismo personaje (1995, I: 937). 
y no una criatura unidimensional como pretendían los sectores más reaccionarios de aquella época ${ }^{38}$.

También Semíramis en La hija del aire es presentada por Calderón desde una doble perspectiva femenina/masculina, encarnando valores pertenecientes a una u otra condición, pero presentes en ella como ser humano completo y diverso. Desde este punto de vista, al enfocar el problema del libre albedrío en Semíramis, el dramaturgo ha convertido la problemática masculina - desde la perspectiva conservadora de aquella sociedaden problemática universal de ambos sexos. Como señala Antonio Regalado, «hay un lenguaje en común en el que participan ambos, varones y hembras, lenguaje que trasciende la dualidad de los sexos y que sirve de vehículo para dar rienda suelta a las íntimas aspiraciones de la persona» (1995, I: 938). Semíramis constituye, en este sentido, la ambición y el deseo de poder y de control sobre las vidas de los demás, pero su personalidad también es enfocada desde una perspectiva absolutamente humana. Tiene derecho a realizar sus propias elecciones aunque éstas la conduzcan hacia el funesto desenlace de su propia muerte. $\mathrm{Y}$ este derecho se convierte en las comedias de Calderón en realidad tanto para hombres como para mujeres. Semíramis es un claro exponente de ello.

2. A través de la simultaneidad de los disfraces masculino y femenino de Lisarda y César en Las manos blancas no ofenden, el dramaturgo propugna la igualdad entre hombres y mujeres de su época desde la consideración de ambos como seres humanos completos.

Tanto Lisarda como César reciben el mismo tratamiento por parte del autor:

- Les guía idéntico móvil: van en busca de la persona amada.

- Ambos abandonan su hogar bajo un disfraz de sexo contrario al suyo.

- Los dos se valen de su apariencia apócrifa para conseguir el amor deseado.

- Emplean el engaño y la mentira como medio de introducirse en la corte de la princesa Serafina.

- Despiertan los celos de otros personajes de su mismo sexo fingido.

- Logran el compromiso matrimonial con la persona amada gracias al disfraz.

38 Para un análisis detallado de la visión de la condición femenina en la antigua sociedad estamental española véase, por ejemplo, Mariló Vigil, 1986; Domínguez Ortiz, 1973b y 1992; VVAA, 1994a y 1994b y Margarita Ortega, 1997. Para el tema misógino desde el punto de vista de la literatura véase, por ejemplo, M.. ${ }^{a}$ del Pilar Oñate, 1938; Rina Walthaus, 1993; M. ${ }^{a}$ Josefa Porro, 1995 y José Luis Canet, 1995. Para una completa bibliografía acerca de la mujer en la literatura del Siglo de Oro, véase primordialmente M. ${ }^{\mathrm{a}}$ Ángeles Calero Fernández, 1996: 189-196. 
Por otra parte, la caracterización afeminada de César y varonil de Lisarda hace fácil el intercambio de los roles sexuales. Una mujer puede comportarse como un hombre debido a su educación y un hombre como una mujer si ha sido ejercitado en las tareas consideradas entonces como femeninas. $\mathrm{Y}$ ambos, al fin y al cabo, se comportan simplemente como seres humanos independientemente de su caracterización sexual. Calderón concede mucha más importancia a la enseñanza y a la educación en que se ha desenvuelto la vida de una persona que a su condición de hombre o mujer, cimentada en la mayor parte de los casos en la tradición. Es la convención social la que induce a unos patrones de conducta heredados a través de los siglos. Así lo expresan los signos lingüísticos procedentes de Lisarda:

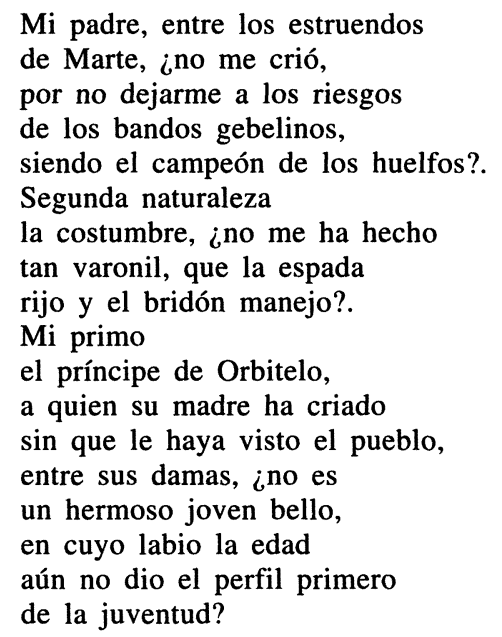

(T. I, I, 1087)

Lisarda había sido educada por su padre dentro del estereotipo de la conducta masculina y César, por el contrario, como una exquisita dama, superprotegido por una madre autoritaria y vigilante. Una vez más las dos caras de la moneda, la dicotomía del ser humano integral sin distinción de sexo sino como criatura multifacética.

La reivindicación de igualdad para hombres y mujeres está plasmada en Hado y divisa de Leonido y Marfisa mediante la defensa del honor de un hombre por una mujer. La disfrazada Marfisa cree muerto a Leónido y se siente en la obligación de sustituirle en el duelo para que nadie piense que el motivo de su ausencia es la cobardía. Finalmente, resulta que Leonido está vivo y que además es su hermano. Asistimos, por tanto, mediante el disfraz, a una inversión de los papeles tradicionalmente asigna- 
dos a los hombres y a las mujeres de aquella sociedad. Desde el plano de la comedia se habían presentado los elementos propiciatorios de este comportamiento poco común en una mujer de aquella época: Marfisa no había sido educada como una dama, sino como un extraño prodigio de la naturaleza en una gruta; su padre adoptivo, Argante, se encuentra ausente cuando Merlín le comunica a Marfisa la muerte de Leónido; se encuentra sola, por tanto, y sin ayuda de nadie para vengar el honor de su hermano y salvaguardar su fama. Marfisa, como vemos, no es una mujer corriente, es un personaje dotado de alma femenina, sí, pero incluso de actitudes autónomas inusitadas en una gran parte de la población femenina de aquella sociedad. La actitud defensora y masculina de Marfisa no sólo se camufla detrás de un disfraz inserto en el plano de la ficción, sino que además viene arropada por un espectáculo teatral y por tanto apócrifo, procedente de todo el ambiente asombrosamente histriónico de la representación dramática.

En Yerros de naturaleza y aciertos de la fortuna, el discurso de la disfrazada Matilde en beneficio de su propio derecho a reinar se convierte, desde el enfoque ideológico, en un alegato a favor de la igualdad entre hombres y mujeres. Mediante su impostura demuestra que es capaz de ejercer el poder exactamente igual que un hombre. Sólo necesita una oportunidad para demostrarlo y como sabe que la sociedad no se lo va a conceder, ella se la otorga a sí misma ${ }^{39}$. Sin embargo, en esta ocasión el fin no justifica los medios, pues se vale de la privación de libertad de otro ser humano: su hermano.

Su intervención se manifiesta, para lograr un mayor impacto histriónico en el espectador, a través de varios mecanismos. Por una parte, constituye una forma de presentación de la disfrazada en la escena, pues acaba de aparecer y ya nos comunica sus intenciones reivindicativas. Por otra parte, el dramaturgo ha optado por su aparición solitaria en el tablado para captar únicamente hacia ella la atención del público y evitar la dispersión mediante las intervenciones de otros personajes. Su discurso tiene fuerza, entusiasmo y profundidad psicológica. La reiteración en forma de estribillo enfatiza la idea de la igualdad propugnada desde el escenario y el reto al que se somete como mujer capaz de llevar a cabo las mismas acciones que un hombre. Por ese motivo Matilde se disfraza varonilmente. Observemos algunos fragmentos de su reivindicativo mensaje:

39 El personaje de Matilde refleja, mediante el uso del travestismo, lo que Antonio Regalado ha hallado en un buen número de casos, referido a la generalidad de la mujer calderoniana: «el dramaturgo dota al personaje femenino de algo más que picardía y atrevimiento, gracia y salero, encandilándolo con el fuego de una poderosísima inteligencia al servicio del deseo y del propio interés. La mujer calderoniana actúa desde la intimidad de su ser, atenta a la supervivencia de su persona frente a las coacciones, censuras y castigos impuestos por la fuerza de la convención, la costumbre y la autoridad» $(1995$, I: 942). 


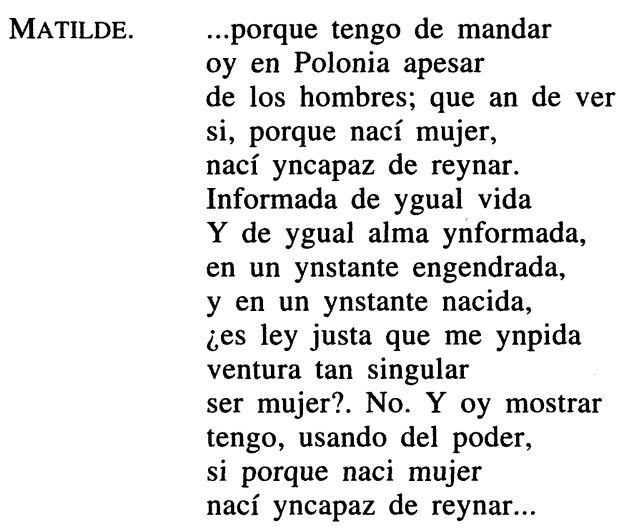

(Jorn. II, 109 y 110) ${ }^{40}$

El traje y la personalidad varonil le van a permitir ejercer el poder exactamente igual que un hombre, incluso con sus mismas pasiones y vicios. Todos somos iguales: seres humanos con cualidades y defectos más o menos pronunciados. En este caso, en la trama argumental la soberbia de Matilde y su desmesurada ambición han de tener un desenlace coherente con su falta de sensibilidad y su falta de respeto hacia otros con tal de lograr sus proyectos. El dramaturgo parece decir sí a la lucha femenina desde su consideración humana, aunque dentro de unos límites y del respeto a sí mismo y a los demás, tanto para hombres como para mujeres, ya que ambos aúnan tanto defectos como virtudes y si no se tienen en cuenta sus derechos, la noble causa corre el riesgo de transformarse en un horror.

3. Crítica de la duplicidad conceptual existente acerca de la mujer en la sociedad barroca ${ }^{41}$ : ensalzada y tratada como una deidad por los parámetros del amor cortés ${ }^{42}$; disminuida, impedida y reprimida por los mecanismos preminentemente masculinos de la época ${ }^{43}$.

40 Citamos por la edición de Eduardo Juliá Martínez, 1930.

41 Jacinto Rivera de Rosales, entre otros, ha apuntado esta idea de forma general sobre el personaje femenino calderoniano (1997: 114). También señalamos la opinión de Octavio Paz recogida, a su vez, por Antonio Regalado y con la que éste muestra su desacuerdo, pues el primero considera que «los poetas rendían culto a la dama ideal, pero eran insensibles a la situación real de las mujeres» (1995, I: 962). Hay que precisar que esta doble actitud existía entre algunos poetas, pero no constituía lo general. En este sentido, Íñigo Sánchez Llama (1993) habla de la visión deformante que algunos poetas tuvieron de sus amadas, aunque también señala la existencia de voces discrepantes que denunciaron la mencionada duplicidad acerca de la mujer. Por otra parte, de todos es conocida la existencia de ciertos autores de tendencia misógina. Para bibliografía sobre este aspecto, véase nota 38.

42 Véase bibliografía en nota 32

$43 \quad$ M. $^{a}$ Grazia Profeti ha hecho hincapié, a lo largo de su artículo, en la posición de inferioridad social de la mujer española en el Siglo de Oro y nombra, a modo de ejem- 
En El José de las mujeres Eugenia es aclamada por el pueblo como novedosa deidad mientras que es tratada como un esclavo por los demás personajes de la obra:

EUGENIA. $\quad$ QQué notable ignorancia
del mundo, pues que no sabe
lo que adora o lo que ultraja!.
¡Oh qué acciones tan contrarias!.
Aquí abaten mi persona,
cuando allí mi nombre ensalzan,
hallándome a un tiempo mismo
allí deidad, aquí esclava;
allí libre, aquí cautiva;
allí divina, aquí humana;
allí en altares, y aquí
de una mujer a las plantas.

(T. II, III, 929)

Mediante el recurso del aparte ${ }^{44}$ el dramaturgo ha puesto en boca de la disfrazada un discurso externamente motivado por el ideal religioso, pero destinado de forma interna a una reivindicación femenina. Se observa la existencia de dos planos paralelos señalados por el empleo de dos deícticos espaciales: «allí» y «aquí», que se repiten a lo largo de toda la intervención, y por la utilización de dos categorías cualitativas antitéticas: la positiva, ensalzadora e ideal; la negativa, represora y peyorativa.

Como decíamos más arriba, el motivo externo elegido es el religioso. La causa de su empleo reside en el conocimiento por parte del dramaturgo del fuerte impacto que tenía el tema en el espectador barroco y la seguridad de que mediante la manipulación histriónica del tema de la conversión al cristianismo de Eugenia se granjeaba el apoyo del público por asociación y traslación de ideas y su simpatía y comprensión hacia las actitudes e ideas procedentes de la disfrazada.

Vamos a analizar detenidamente el discurso de Eugenia desde la doble intencionalidad del dramaturgo en su aspecto dicotómico y simbólico: amor cortés/realidad social femenina barroca. No se debe dejar de lado, claro está, la dimensión de tópico literario que adquiere así mismo el tratamiento de este tema en las tablas, pues era muy del gusto del público barroco

plo, un testimonio literario: la protesta de las mujeres en la Hora de todos de Quevedo contra su inferioridad social y legal, con la respuesta violenta del escritor (1995: 236). M. ${ }^{a}$ Josefa Porro abunda también en este tema, señalando la función de Quevedo al retomar la antorcha del antifeminismo en una tendencia cuyos orígenes se funden con los propios de la literatura (1995: 92).

44 Acerca del recurso del aparte es preciso mencionar los ya clásicos estudios de Emilio Orozco (1969 y 1983), en que se analiza su función de conmover al público y hacerle participar en el conflicto del personaje. 
y, en concreto, del femenino y constituía un elemento fundamental con respecto a la teatralidad de la escena.

Los aspectos del amor cortés señalados en el mensaje de la disfrazada y que evidencian la figura de la mujer como objeto de veneración son:

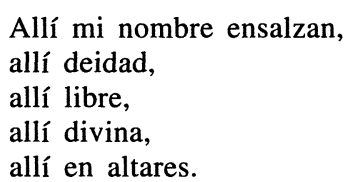

(T. II, II, 929)

Ésta es, como hemos dicho, la visión ideal de la mujer como punto de mira del amor cortés: una diosa ensalzada por su belleza, subida en un pedestal ideal y libre por tener a sus pies a un caballero que satisface absolutamente todos sus deseos.

Por otra parte, observamos en clara antítesis con los elementos anteriores, los aspectos de la realidad social barroca que constituyen la imagen de la mujer acerca de sí misma y su sentimiento auténtico:

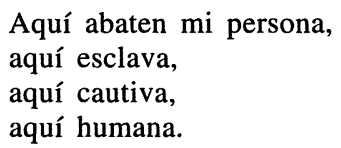

(T. II, II, 929)

Y ésta constituye la visión real femenina de aquellos tiempos: abatida por el universo masculino, que no permitía su ascensión dentro de las relaciones sociales y culturales; esclava, pues le era impuesta una ideología y una forma determinada de vida, aunque ella no estuviera de acuerdo; cautiva en su propio hogar, ya que le estaba prohibido salir sola en multitud de ocasiones; humana, tremendamente humana y en absoluto deidad, ya que era apartada conscientemente de ejercer influencia alguna sobre una sociedad poderosamente masculina.

4. Crítica de la situación de inferioridad ${ }^{45}$ del sector femenino. Mediante el disfraz de Hércules en Fieras afemina amor asistimos a una

45 Acerca de la situación de inferioridad de la mujer en el Antiguo Régimen véase, entre otros, Paloma Cepeda Gómez, 1986; Fernández Vargas y López Cordón, 1986; Mariló Vigil, 1986; VVAA, 1988; Isabel Barbeito, 1992; Domínguez Ortiz, 1992; A. Farge y N. Davis, 1992; O. Hufton, 1992; M. ${ }^{a}$ Gloria Ródenas y Susana Vicent, 1992; Margaret L. King, 1993; Isabel Pérez Molina, 1994; Giulia Calvi, 1995; M. ${ }^{a}$ Josefa Porro, 1995; Bravo Lozano, 1996; Cristina Segura Graíño, 1996; Margarita Ortega López, 1995 y 1997. 
inversión de los papeles tradicionalmente asignados a hombres y mujeres. En la comedia encontramos de forma inmediatamente posterior al disfraz, el reflejo de esta ideología mediante el recurso del diálogo musical entablado entre varios personajes de la comedia:

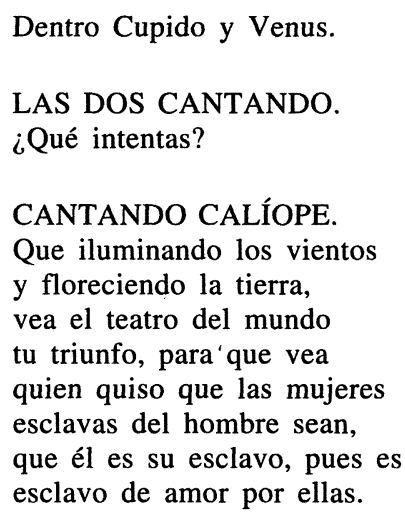

(T. II, III, 2062)

Yole, como mujer ofendida, toma la iniciativa y adopta una resolución activa con respecto a su propio destino. No desea casarse con Hércules ni compartir con él su reino, por ello decide disfrazarlo de mujer, humillarlo y exhibirlo públicamente. Bajo el disfraz femenino, Hércules se halla realmente en la piel de una mujer de aquellos tiempos: indefenso, en manos de otros, ultrajado y sometido. Y todo ello con el agravante de que el disfraz se superpone a la identidad de un hombre acostumbrado a luchar por sus propias ideas y a triunfar. Así como el disfraz varonil permite que aflore del interior de la mujer su verdadero valor, oculto y reprimido por la sociedad barroca bajo la identidad femenina, el disfraz femenino pone de manifiesto en el disfrazado la debilidad y el sometimiento de la mujer barroca ante la superioridad social del hombre en una sociedad patriarcal. Por otra parte, en el personaje femenino de Yole se refleja la idea de la superación de la mujer aún en inferioridad de condiciones mediante el desarrollo de su ingenio. Logra la victoria sobre el hasta entonces invencible Hércules, caracterizado como hombre fuerte y misógino, y se venga de la muerte de su padre y de su esposo.

5. Parodia de los patrones propugnados para el comportamiento de los hombres de aquella sociedad con respecto a las mujeres. A través de la escena cómica entre Don Diego y el gracioso Mosquito en $E l$ escondido y la tapada, el dramaturgo pone en tela de juicio, a través de la parodia, un patrón de conducta propugnado para el caballero noble, proce- 
dente de la creencia en la virtud heredada. Al caballero se le presuponen una serie de valores como la valentía y el arrojo propios de los héroes, que no podían faltar en don Diego, como caballero perteneciente al estamento nobiliario ${ }^{46}$. Sin embargo, esta vez no emplea estas actitudes tópicas en el momento oportuno ni con la persona adecuada, pues es engañado por Celia y utiliza sus maneras corteses con un gracioso disfrazado de mujer y no con una verdadera y afligida dama como él imagina. Se trata de Mosquito. Éste intenta no ser reconocido y por ello permanece en un absoluto mutismo. Sólo interviene a través del recurso del aparte, mediante el cual el dramaturgo permite la comunicación con el público y únicamente con él. La comicidad de esta escena se constituye como una cadena de eslabones lingüísticos ${ }^{47}$ que tienen un receptor distinto en cada ocasión y que no siempre obtienen una respuesta directa. En primer lugar, Don Diego lanza su mensaje hacia la que cree que es la dama tapada que ha acudido a él en busca de protección de un supuesto hombre que la ha deshonrado y que la persigue. En realidad ésta es Mosquito disfrazado con las ropas de Beatriz. Permanece en silencio para que su voz no le delate y aprovecha la circunstancia de la oscuridad de la noche. En segundo lugar, el disfrazado lanza su mensaje al público mediante el recurso del aparte, aunque esta vez sí obtendrá respuesta: su risa. La comicidad se deriva, por tanto, de la inadecuación entre los comentarios galantes de don Diego y la recepción de los mismos por Mosquito. Éste no conoce la existencia de una tapada ${ }^{48}$ que ha acudido hasta el caballero en busca de ayuda y que manifiesta su complacencia mediante el recurso del aparte. En estas palabras dirigidas al espectador se observa la existencia de la ironía y de tópicos relativos a la galantería externa del caballero hacia la dama. Por ello, Mosquito desea vestirse eternamente con un traje de mujer:

46 Acerca de las características adjudicadas al noble véase, por ejemplo, J. M. Díez Borque, 1976: 276. También M. ${ }^{a}$ Victoria Morales, entre otros, se refirió, en un breve estudio de la función de la figura femenina en algunas comedias de enredo de Calderón, a los patrones de conducta que se presuponen en un individuo por ser noble de nacimiento (1983: 6).

47 Maravillas Larrañaga Donézar hizo hincapié en la variedad que ofrece el lenguaje de Mosquito y en su rasgo de alejamiento de las normas de cortesía (1989). Véase también, entre otros, Ruano de la Haza, 1994b.

48 La tapada se presenta en esta comedia, como en otras de enredo, como motivo central junto con el recurso del disfraz. Supuestamente, esta práctica tiene por propósito salvaguardar la honra de la mujer, pero en el ámbito de la comedia se presta a una serie de confusiones y de engaños. Sobre este uso en la comedia véase, por ejemplo, M. ${ }^{a}$ Victoria Morales, 1983. En la sociedad barroca, entre otros, Castro y Rossi, 1881; Bomli, 1950; M. ${ }^{a}$ José Sáez Piñuela, 1965; Deleito y Piñuela, 1966; Marcellin Defourneaux, 1983; Néstor Luján, 1988; Díez Borque, 1990; Antonio Domínguez Ortiz, 1992; Natividad de Diego y África León, 1995. 


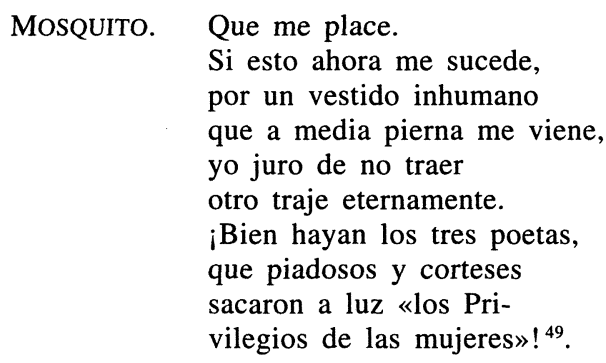

$$
\text { (T. II, II, 695) }
$$

El silencio del disfrazado no despierta las sospechas de don Diego, sino más bien su compasión hacia el disgusto y la timidez que encuentra lógicos en una señora. Calderón nos presenta a través de la función cómica de este disfraz la falsa imagen de la mujer como ser silencioso ${ }^{50}$ y tímido que representa Mosquito de forma involuntaria al verse inmerso en aquella situación. Ello es debido a una confusión de don Diego, quien piensa que es la dama que hace un momento ha solicitado su auxilio. Esta característica es aceptada por él como un rasgo natural de ella. En esta ocasión, el recurso utilizado por el dramaturgo ya no es el diálogo sino el aparte destinado al público. Don Diego se muestra, no sólo en este momento sino también en la escena anterior, como el caballero dispuesto a defender a la dama simplemente por razón de su sexo y de su aflicción:

$\begin{array}{ll}\text { DIEGO. } & \text { Callad, } \\ & \text { no digáis más, que no deben } \\ & \text { escuchar los caballeros } \\ & \text { más razón a las mujeres } \\ & \text { para ampararlas, que verlas } \\ & \text { afligidas. } \\ & \text { (Aparte). } \\ & \text { ¡Pobre señora! Afligida, } \\ & \text { aún a hablarme no se atreve. }\end{array}$

(T. II, II, 694 y 695)

49 Nos hallamos ante una ruptura de la ilusión escénica, tan frecuente en las obras de Calderón. Se alude a la comedia El privilegio de las mujeres, en la que colaboraron con nuestro dramaturgo, Coello y Solís. Acerca de las comedias de Calderón en que se produce la burla de las convenciones teatrales y la ruptura con la ilusión escénica, véase Victoria B. Torres, 1987; Carmen Bravo-Villasante, 1944, 264-268; Georges Güntert, 1977; Claire Pailler, 1980; Alberto Navarro, 1983; Ignacio Arellano, 1986; Susana Hernández Araico, 1986 y Alfredo Hermenegildo, 1995, entre otros.

so El silencio, la timidez y la obediencia eran las cualidades más apreciadas en una mujer, pues suponían sumisión con respecto al varón. En este caso, el silencio de Mosquito constituye un recurso para pasar desapercibido, pero también un mecanismo que conecta con la realidad cotidiana de la mujer. En otras obras de Calderón, el silencio no se halla inmerso en una escena cómica, sino en una situación de drama. En este sentido, Marie-Françoise Déodat-Kessedjian ha tratado de demostrar que el silencio de la mujer no revela sumisión, sino dominio de sí misma (1996). 
Esta escena parte de una dimensión cómica en apariencia ridiculizadora del gracioso, para adentrarse después de un análisis profundo, apartado de todo prejuicio anterior, en una crítica solapada de las maneras obsoletas de ciertos hombres que se creían caballeros por guardar unas maneras externas con respecto a las damas, paralelamente a una desmesurada actitud en relación con otras cuestiones morales resueltas drásticamente a través de las armas. Se nos presenta una conducta irracional, pero en lógicas etapas. Es, pues, como ha señalado Ruano de la Haza refiriéndose, en general, a las comedias lúdicas, un absurdo racional y lógico basado en los dos grandes móviles de las comedias lúdicas: el código del duelo y el código del galanteo (1994b: 280). Don Diego, como hombre típico de la época, mantiene externamente las maneras propugnadas para los caballeros nobles de aquella época. Su actitud entusiasta ante la defensa de un ideal encuentra amparo en un ciertó quijotismo ${ }^{51}$ que se presenta en la comedia desde la perspectiva de la parodia. Pero en ningún momento se desprende una sonrisa amarga de la escena del disfraz, sino que la ironía y la sátira se funden con una profunda ternura hacia sus personajes por parte de Calderón.

En El castillo de Lindabridis, a través del disfraz de caballero andante de la disfrazada Claridiana y reforzado por el comportamiento de otros personajes masculinos de la comedia, se parodia la figura del caballero anclado en un tiempo pretérito. Éste, como acabamos de ver, se caracterizaba por la defensa de ideales absurdos hasta límites insospechados en nombre de una idea algo obsoleta del amor y del honor, pero despertaba gran entusiasmo en el marco del ambiente cortesano de aquella época ${ }^{52}$ :

51 En este sentido se puede observar la huella cervantina en Calderón, pues, como ha señalado Pérez Rioja entre otros, los caballeros andantes recorrían el mundo armados con su espada o lanza, dispuestos a batirse contra aquel que no reconociera la estirpe y la belleza de su dama (1983: 193 y 194). También se puede ver esa misma huella en otras obras de nuestro dramaturgo como No hay cosa como callar, El astrólogo fingido, El mayor encanto amor, El médico de su honra, El gran mercado del mundo, etc. Acerca de la influencia de Cervantes en Calderón véase, por ejemplo, Alberto Sánchez, 1957; Cesáreo Bandera, 1975; Manuel García Martín, 1980; Ciriaco Morón Arroyo, 1982; José Ángel Ascunce, 1983; Oscar Pereira, 1989 y Ana Suárez Miramón, 1999. Antonio Regalado señala las obras en que los personajes calderonianos muestran afición por las novelas de caballerías. También hace referencia a la parodia a que estuvo sujeto el ideal caballeresco procedente de Don Quijote, ya que éste representó un paradigma de la inversión cómica de ese ideal (1995, II: 499 y ss.). Sobre la influencia de los libros de caballería en el teatro de Calderón, Valbuena Briones, 1982: 1-8. Para un punto de vista cómico sobre la alusión al mundo de la caballería andante, véase, sobre todo, Autora Egido, 1989: 220.

52 Alicia López de José recoge datos sobre las formas de galanteo en la Corte de Felipe IV (1997). Antonio Regalado se hace eco también del entusiasmo existente en el contexto cortesano hacia formas arcaicas que inspiraron la nostalgia de un estilo de amar asociado con las novelas de caballería (1995, II: 499). 
FEBo. $\quad$ Hoy no riñe aquí el amor; riñe el honor, porque entiendas que el que en la ocasión se halla, aunque a la dama no quiera, debe por ella reñir, si le da ocasión ella.

(T. I, II, 2078)

El refuerzo de esta idea, transmitida básicamente desde los comportamientos parodiados a través de la disfrazada y alrededor de ella, procede de la mirada crítica del gracioso ${ }^{53}$ Malandrín, que desempeña el papel de escudero. Así, por ejemplo, en un momento determinado de la comedia, se convierte en escudero de un «salvaje andante», refiriéndose al Fauno. El comportamiento de éste encaja a la perfección en el estereotipo de actuación del caballero andante: va en busca de una dama de quien se siente enamorado, por ella es capaz de emprender cualquier acción y cuenta con la colaboración de un escudero:

FAUNO. Desde hoy serás mi guía. Ven conmigo. Lindabridis, espera, ya te sigo.

Vase.

MALANDRÍN. Venme aquí en un instante hecho escudero de un salvaje andante.

(T. I, II, 2072)

A través de la intervención lingüística de Malandrín, el dramaturgo elabora un tipo de construcción en que «salvaje» y «caballero» se encuentran en relación paradigmática, en posición intercambiable y compartiendo cierta similitud de contenido ideológico, oculto bajo la apariencia de la implacable visión burlesca del gracioso.

En la mojiganga La garapiña el dramaturgo pone de manifiesto la absurda idea de que el caballero de aquella época tuviera que satisfacer todos y cada uno de los deseos de su dama. En este caso, doña Blasa exige a don Gil que le traiga flatos, pues sabe que están de moda entre las da-

53 Los graciosos calderonianos se caracterizan frente a sus predecesores por su capacidad crítica. También se puede observar este mismo rasgo de la alusión cómica a la caballería andante en otros graciosos, como por ejemplo Lebrón en La fiera, el rayo y la piedra (Aurora Egido, 1989: 220). Sobre el papel cómico del gracioso véase, entre otros, Charles David Ley, 1954; George Güntert, 1977; R. Jammes, 1980; M. ${ }^{a}$ Grazia Profeti, 1980; Claire Pailler, 1980, Manuel Antonio Arango, 1980; Alberto Navarro González, 1983; Luciano García Lorenzo, 1984; Ignacio Arellano, 1986; F. Serralta, 1990 y 1994; Ana Suárez Miramón, 1993b; VVAA., 1994c; Alfredo Hermenegildo, 1995; Evangelina Rodríguez Cuadros, 1998; Peter Thompson, 1998 y M. ${ }^{a}$ Luisa Lobato, 1994 y 1998. 
mas más refinadas y populares. Él trata de explicarle, pero ella no atiende a razones. Sólo desea poseer aquello que la convertirá en una dama esnob. Él, como caballero que se considera, resuelve el dilema comprando una mezcla de bebidas altamente indigestas, que de seguro le proporcionarán flatos.

Don Gil representa la parodia del estereotipo de caballero capaz de realizar cualquier acción por satisfacer a su dama. Claro que en este caso, la dama no se comporta como tal, pues le da a elegir entre la satisfacción de sus anhelos o el abandono y no le da opción a explicaciones. Él, por su parte, tampoco actúa muy refinadamente, pues en lugar de actuar con sentido común, proporcionará a su dama una mezcla que de seguro le provocará una enfermedad. Y es que las exigencias de aquella sociedad conservadora también eran injustas para con los hombres, obligados en muchas ocasiones, por mantener su reputación de caballeros, a realizar acciones ingratas también para ellos, aunque se tratara de «boberías»:

\section{GALÁN. Cortesanías son desempeños de las boberías.}

$$
\text { (p. } 390 \text {, vv. } 84 \text { y } 85 \text { ) }
$$

6. Parodia de las relaciones entre hombres y mujeres. Mediante la actitud de Claridiana, una de las disfrazadas de la comedia El castillo de Lindabridis, se pone de manifiesto mediante el recurso de la parodia, la crítica hacia las relaciones entre los dos sexos en aquella época ${ }^{54}$, basadas, por una parte, en la superficialidad:

$$
\begin{aligned}
& \text { Claridiana. ¿Qué frías son las finezas } \\
& \text { que se dicen sin el alma!. }
\end{aligned}
$$

$$
\text { (T. I, II, 2077) }
$$

Y, por otra, en el vacío y exagerado discurso amoroso del caballero hacia la dama, cimentado en unas formas externas caducas, trasnochadas y carentes de toda coherencia y sentido con respecto a la intimidad y sinceridad que se supone imprescindible en toda relación amorosa:

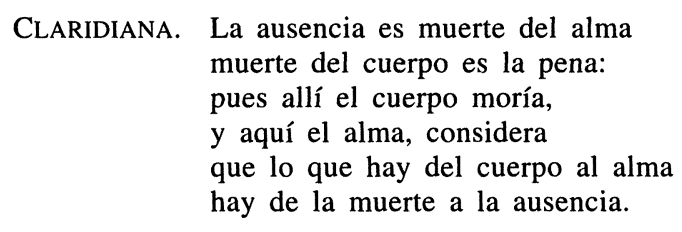

\footnotetext{
${ }^{54}$ Acerca de las relaciones entre hombres y mujeres en los siglos XVI y XVII véase, entre otros, el estudio de Agustín Redondo, 1995 y Alicia López de José, 1997.
} 
LINDABRIDIS. Si para morir de ausente viviste de amante, deja el necio argumento, pues también quien muere se ausenta.

(T. I, II, 2076)

Otra muestra de la superficialidad en las relaciones hombre-mujer se basa en el empleo del súbito enamoramiento ${ }^{55}$ de Lindabridis hacia Claridiana disfrazada varonilmente. Éste no es un recurso exclusivo de las comedias, sino que es también empleado por nuestro dramaturgo en los autos sacramentales. Así, en El gran mercado del mundo, la Lascivia se enamora de la Culpa creyendo que se trata realmente de un mozo de mesón. En El año santo de Roma, el Hombre se enamora de la apariencia y el mensaje engañosos de Lascivia. En , El viático cordero, Zambrí se enamora de la Idolatría disfrazada de dama. En El arca de Dios cautiva, también es la Idolatría, pero esta vez disfrazada de rústica villana, quien logra enamorar a dos personajes israelitas, Irán y Abiud. Éstos, a pesar de ser avisados por Ofní y Fineés, se muestran hipnotizados hacia la belleza de la villana. Todos estos enamoramientos muestran en común la característica de la belleza externa y la ficción del personaje disfrazado y las mentiras para sus conquistas. Todo ello evidencia el desconocimiento de un sexo hacia el otro y la ignorancia existente en aquel tiempo dentro del terreno amoroso, en que las relaciones amorosas estaban basadas, en gran parte, en el atractivo físico, en las falsas promesas y en una idea estereotipada del galán y de la dama. Las hazañas heroicas y los alardes de honor eran los parámetros en los que se insertaban las maneras del caballero propugnado por las instancias aristocráticas de aquel tiempo ${ }^{56}$.

En el entremés El sacristán mujer, Mari López aparece durante toda la pieza vestida de sacristán y compite con otro hombre por el amor de la dama. La elección de Brígida hacia ella pone de manifiesto, mediante la

55 J. M. Díez Borque constata la aparición del «súbito enamoramiento» en todas las comedias que él ha estudiado y afirma que se trata de un artificio literario, claramente separado de la realidad, en el que se apoya la estructura de la comedia y que no difiere esencialmente de formas de literatura amorosa infraliteraria (1976: 28). M. ${ }^{2}$ Pilar González Velasco señala que se trata de un recurso debido a la economía teatral, que no permitía exponer en escena el largo proceso del enamoramiento (1989: 121). Nosotros consideramos que la existencia y éxito de tal artificio constituye, por supuesto, un tópico teatral, pero su uso masivo también se halla en conexión con ciertos elementos cotidianos y con los gustos del público barroco y constituye una manera de abordar la crítica de las relaciones superficiales y poco sólidas entre hombres y mujeres. Para la realidad de estas relaciones véase la bibliografía mencionada en la nota anterior.

56 Alicia López de José señala la dureza de los decretos tanto de Felipe III como posteriormente de Felipe IV, relativos al galanteo de los caballeros hacia las damas para evitar la degradación de las formas caballerescas tradicionales y frenar cualquier posible pérdida de los privilegios de la nobleza (1997: 215). 
utilización del tópico del enamoramiento de la dama hacia la disfrazada ${ }^{57}$, la absurda idea de la relación hombre-mujer en aquella época, en que el amor podía generarse a través de certámenes o simplemente a partir de retratos ${ }^{58}$.

7. Crítica de ciertas modas femeninas instaladas en la sociedad barroca. En la comedia Amor, honor y poder se pone de manifiesto, a través del disfraz varonil de la infanta Flérida, la crítica del dramaturgo hacia la moda imperante tanto para hombres como para mujeres, de ocultar su identidad bajo mantos o rebozos. El mensaje verbal de su amado Enrico da a conocer la apariencia encubierta de la infanta, quien además de ir vestida de hombre, tapa su rostro para no ser reconocida:

ENRICO. Pues, 'iqué puede haber que intentes, callando el nombre y guardando el rostro?

(T. I, III, 82)

Enrico está preso y la infanta, disfrazada, ha podido acceder hasta él y le ha hecho una propuesta de dinero y caballos para poder escapar. El diálogo entre Enrico y la infanta se convierte en una verdadera reflexión del primero acerca de la costumbre de encubrirse. La forma argumental empleada es el deseo de conocer la identidad de una persona que intenta ayudarle, pero de quien no se fía por ir encubierto:

ENRICO.
... sólo
queseo saber quién eres;
y casi infame poca nobleza,
quien satisfecho no obliga,
y obligado no agradece.
¿Cuándo en el mundo se usa
encubrirse? Quien ofende
se encubre; quien hace bien,
casi imposible parece.

(T. I, III, 82)

\footnotetext{
57 El enamoramiento hacia el personaje disfrazado es un recurso empleado por Calderón en toda clase de obras, como por ejemplo, en los autos La protestación de la fe y El gran mercado del mundo o las comedias El castillo de Lindabridis, El José de las mujeres, etc.

58 Esta crítica aparece también en otros entremeses como El Toreador, en que Juan Rana se enamora de una dama por medio de un retrato de ella. En Tirso de Molina asistíamos al extremo de lo absurdo mediante el disfraz varonil de Serafina (El vergonzoso en palacio), quien se enamora de su propio retrato disfrazada de hombre.
} 
El comportamiento previo de Enrico como hombre de estricto honor hace posible su actitud coherente y deseosa de claridad y otorga autoridad a su discurso. No anhela la libertad si ésta procede de alguien que se esconde, pues sus intenciones, entonces, no serán muy de fiar.

Mediante esta nueva intervención de Enrico, el dramaturgo ya no se conforma con reflejar una acostumbrada y entusiasta moda seguida por los hombres y las mujeres del Barroco, sino que se convierte en portavoz de un malestar existente en el sector más intelectual de la sociedad, procedente de considerar esta moda como falsa y encubridora. Deleito y Piñuela (1966) recoge el pensamiento de algunos historiadores y escritores que condenaban el uso de mantos y rebozos. Entre ellos, el historiador Antonio de León Pinelo. En su obra Velos antiguos y modernos en los rostros de las mujeres. Sus conveniencias y daños. Ilustración de la Real Premática de las tapadas, alude a la pragmática de 1639 que las prohibió y fue la ocasión de escribirse la obra. También Ángel Stor y Fray Juan de la Puente, entre otros, dedicaron tiempo y esfuerzo a la crítica de ciertas formas de taparse. Los Avisos de Pellicer se convirtieron en espejo de la realidad social del momento. Pérez de Sala señaló cómo en aquella sociedad el manto se elevaba al rango de institución y desempeñaba tan importante papel que las más severas prohibiciones no lograron desterrar su uso.

La causa del rechazo hacia tal moda residía en que mantos y rebozos no sólo se empleaban en aquellos tiempos como medio de coquetería y donjuanismo ${ }^{59}$, sino que además era uno de los motivos frecuentes de lances callejeros ${ }^{60}$. Por otra parte, los detractores afirmaban que bajo estos instrumentos de hábil ocultación se llevaban a cabo delitos variados ${ }^{61}$. El manto, la capa o el rebozo, como elementos encubridores, permitían pasar de la libertad al libertinaje e incluso al delito con gran facilidad. Muchos eran los que estaban en contra de ello, como hemos apuntado, pero también mucha la población interesada bien en esconderse tras ellos, bien en

59 Desde esta perspectiva aparece reflejado su uso en algunas obras del teatro barroco español. A modo de ejemplo se pueden nombrar, entre otras, El acero de Madrid de Lope de Vega, El amor médico de Tirso de Molina, El escondido y la tapada de Calderón de la Barca y Los empeños de una casa de Sor Juana Inés de la Cruz. A este respecto señala Antonio Domínguez Ortiz que su derivación de costumbres musulmanas es discutible, puesto que no utilizaban el velo para pasar desapercibidas sino para distinguirse, con escándalo de los puritanos (1992: 308).

60 Madame d'Aulnoy señala el peligro de las mujeres tapadas de ser molestadas por hombres que desean pretenderlas y añade que «lo más delicioso es que puede ser el marido quien cierra el paso al nuevo pretendiente para que la mujer no halle obstáculos que la impidan llegar a los brazos de su amante» (Recogido por Deleito y Piñuela, 1966: 209).

${ }_{61}$ Néstor Luján, por ejemplo, recoge datos sobre la existencia de maleantes variopintos que se valían de diversas tretas, entre ellas el ocultamiento de su verdadera identidad, para robar e incluso asesinar (1988: 185). 
aderezarse a la moda de la época sin pararse a reflexionar sobre las consecuencias de esa extravagancia social y cultural. Calderón se convierte, mediante la intervención de la disfrazada y tapada infanta Flérida, en un reinvindicador de la desaparición de tal moda, aunque no es el único dramaturgo que propugna la abolición de un uso determinado en boga dentro de aquella sociedad extremadamente estereotipada y teatral. Recordemos, por ejemplo, que la moda del guardainfante fue criticada por numerosos autores contemporáneos a través de la sátira burlesca. Quiñones de Benavente, Rojas e incluso el mismo Calderón en algunas de sus obras ${ }^{62}$ se hacen eco de esta absurda moda. Ana Suárez Miramón (1993b) constata en un espléndido trabajo sobre esta prenda y el personaje que lleva su nombre en el teatro de Rojas, la influencia social que tuvo a través de abundantes testimonios barrocos.

Dentro de la misma tendencia de criticar el seguimiento de ciertas modas, en la mojiganga La garapiña se pone de manifiesto la tendencia existente en algunas mujeres de aquella sociedad de adherirse a una moda sólo por el deseo de asimilarse a las demás. En esta pieza, doña Blasa y doña Lázara desean fervientemente los flatos sólo porque las damas de su entorno confiesan tenerlos, aunque desconocen ${ }^{63}$ absolutamente el significado de esta palabra:

$\begin{array}{ll}\text { BLASA. } & \text { ¿Qué son flatos? } \\ \text { LAZARA. } & \text { Amiga, } \\ & \text { no sé qué son ni sé lo que te diga, } \\ & \text { porque sólo sé dellos } \\ & \text { que no hay (para decirle sin arenga) } \\ & \text { dama de garbo ya que no los tenga } \\ & \text { o muera por tenellos } \\ \text { ¿Quasa. uso es éste que a mí llega tan tarde? } & \text { Flatos hay en el mundo (¡oh, ansias fieras!) } \\ & \text { y no he entrado yo en él de las primeras, } \\ & \text { siendo tan primorosos y tan bellos } \\ & \text { que Lázara se muere por tenellos... } \\ & \text { ¿Si serán perendengues o tirantes... } \\ & \text { Mas sea lo que fuere, el día que pasa } \\ & \text { por uso nuevo, yo... }\end{array}$

(p. 386, v. 9 y ss.)

${ }^{62}$ Por ejemplo en No hay burlas con el amor, El privilegio de las mujeres y Guárdate del agua mansa.

63 Evangelina Rodríguez y Antonio Tordera señalan un recurso de ironía sobre el desconocimiento de las mujeres hacia ciertos significados (1982: 386, n. 9). Nosotros consideramos, matizando algo esta apreciación, que el desconocimiento es utilizado para la presentación de la crítica del seguimiento de las modas por absurdas e incómodas que fueran aun sin saber en qué consistían. 
Doña Blasa exige a su galán, don Gil, que se los proporcione. Éste, en su empeño de rendir servicio a su dama como buen caballero, acude a un establecimiento de bebidas y le compone una mezcla de seguro flatulenta. La aparición de Escamilla disfrazado de doña Aloja, simbolizando la fuerza de la razón por descubrir los insanos efectos de las bebidas preparadas por don Gil para producir flatos en doña Blasa, desengaña a ambas damas sobre la realidad y el significado del mismo. Calderón ha disfrazado de mujer al actor en un intento de benevolencia hacia el deseo de las mujeres de la época de ser cada una la más esnob al tratar de imitar las maneras y costumbres de las que consideran más distinguidas. La razón llega de la mano de un disfraz femenino:

$\begin{array}{ll}\text { ESCAMILla. } & \text { Contrabandos de garganta... } \\ & \ldots \text {..Y tú, } \\ & \text { daca esa redoma, daca, } \\ & \text { que a vista de todos quiero } \\ & \text { desengañar a las damas, } \\ & \text { cuando médica de flatos } \\ & \text { soy calavera de ansias. } \\ & \text { ¡Oh fuerza de la razón, } \\ \text { Tode a todas haces rendir } & \text { a tus pies! }\end{array}$

(p. 402 , v. 293 y ss.)

Doña Blasa, efectivamente, comprende y renuncia a tal moda.

Javier Huerta Calvo (1983: 810) ha señalado la existencia de crítica misógina tanto en esta obra (considera que se presenta la caricatura de las mujeres con afán de estar a la moda), como en otras piezas breves calderonianas (a través de la ridiculización de la mujer piadosa: La casa de los linajes). M. ${ }^{a}$ Luisa Lobato (1997: 137), por el contrario, habla de la supremacía femenina frente al varón víctima de sus estratagemas, aunque en el contexto del entretenimiento, lo cómico y lo grotesco o exagerado. Por supuesto, la sátira está presente en el mismo y constituye, como ya hemos mencionado, uno de los rasgos de las piezas cortas. Como señala Evangelina Rodríguez Cuadros (1997: 128), el entremés o cualquier género menor reflejan la realidad, pero nunca de manera neutra. Por supuesto, como ya descartó Eugenio Asensio (1971), no se trata de un costumbrismo nostálgico o evocador a la manera de Mesonero Romanos, ni siquiera crítico a la manera de Larra. Es más bien un costumbrismo evasionista y satírico. Sin embargo, hemos de separar claramente aquella crítica costumbrista ${ }^{64}$ expresada por Calderón mediante todos esos procedimientos, y el odio hacia las mujeres presente en toda misoginia. Por el contrario, Calderón se mues-

64 También Catalina Buezo habla de costumbrismo en las piezas breves al clasificar esta obra como «mojiganga entremesada de tipo costumbrista» (1997: 132). 
tra partidario de la mujer, pues la considera víctima de los excesos de la sociedad barroca, pero no por ser mujer, sino como simple ser humano. En el caso de La garapiña, su sátira se halla más relacionada con la exhortación a un cambio de actitud por parte de muchas de las mujeres de la época que con la misoginia. Recordemos las críticas que despertaban igualmente otras modas femeninas como por ejemplo el guardainfante o los chapines por ser considerados rémoras para el avance social de las mujeres barrocas. La exhortación de dramaturgos como Calderón va encaminada a despertar a una gran parte de las mujeres del letargo ingenuo e inconsciente de las rancias costumbres y modas que las mantenían sometidas dentro de un orden conservador conveniente para el sector masculino de la sociedad barroca. La risa que provoca esta mojiganga en el público no es hiriente ni cruel sino simpática y benevolente. Por todo ello no podemos considerar como misógino el discurso de Calderón en esta mojiganga.

El travestismo calderoniano funciona, desde la perspectiva ideológica de la mujer, como mecanismo para explorar valores y comunicarlos. Se convierte en símbolo, así como el espacio escénico en que se desenvuelve, de una moderna visión femenina. Anteriormente, las disfrazadas se caracterizaban, en general, por rasgos como el juguetón, enredador, amable y gracioso. Necesitaban el atuendo varonil para expresar unas actitudes de ordinario incluidas en un ámbito de naturaleza masculina. Pero, sobre todo, se mostraban profundamente femeninas. Incluso doña Serafina ( $E l$ vergonzoso en palacio de Tirso de Molina), que se disfraza por diversión y por deseo de convertirse en un hombre, exhibe cualidades netamente femeninas en contradicción con su anhelo. Las disfrazadas calderonianas retoman los parámetros de sus predecesoras como el ingenio, la adaptabilidad y la actitud reivindicativa, pero llevan a cabo una profunda renovación. Aunque se ayudan del travestismo para llevar a cabo acciones transgresoras, no precisan un disfraz para exhibir una naturaleza fuerte y masculina. Son mujeres caracterizadas, en su mayoría, por el rasgo varonil. Sólo tomando en consideración las comedias, de un total de 13 en que aparece el recurso del travestismo, en 11 hay mujeres disfrazadas varonilmente -en otras dos son hombres los que se visten de mujer-, y de éstas, en 7 se halla el rasgo varonil, lo que representa el $64 \%$ sobre el total de 11 . Se ha pasado de la ausencia completa de este tipo de mujer en la comedia de Lope o de Tirso a la proliferación del mismo en la comedia calderoniana. Esta novedad se puede interpretar en relación con la presentación de una mujer distinta que se erige, no ya en representante del sexo femenino, sino de un ser humano completo y diverso. La mujer, aun sin disfraz, rebasa los límites de la esfera femenina para alcanzar los de la humanidad sin distinción de sexos. Sin embargo, sigue necesitando el disfraz masculino para llevar a cabo acciones y movimientos espaciales que adquieren carácter simbólico y que le están prohibidos por el simple hecho de ser mujer. Por otra 
parte, la visión progresista de la mujer que ofrece Calderón en su teatro es presentada a través del recurso de la plasmación de las convenciones sociales, de la utilización de un marco social cotidiano de valoración positiva de lo masculino y de aspectos fácilmente reconocibles por la inmensa mayoría de los espectadores dentro del plano de la comedia. Es una manera de conectar con la realidad diaria como medio para captar su atención y a partir de ahí poder presentar su ideología mediante la creación de un espacio ficticio representado por el disfraz. El travestismo se convierte, así, en metáfora de la fuerza que permite la lucha contra el anquilosamiento de la sociedad y que devuelve a la mujer la vitalidad inherente a ella como ser humano. Y Calderón en precursor de una consideración moderna de hombres y mujeres como seres humanos iguales y a la vez únicos y variados. Aún en nuestros días el espacio femenino sigue caracterizándose en algunos sectores por la restricción o lá escasa representación. La búsqueda de su identidad guía muchas de sus reivindicaciones incluso hallándonos ya inmersos en un nuevo milenio. Calderón se anticipó de forma clarividente a esta actitud. Por ello la lectura actual de su teatro adquiere el sello de la vigencia desde una doble perspectiva: la denuncia del escaso desarrollo y marginación de la mujer y la exhortación solapada a una postura activa y dinámica por parte de todo el sector femenino. En definitiva, la mujer es contemplada por Calderón como protagonista de su propio cambio, pero sobre todo como un ser humano poliédrico, como un «pequeño cielo» desde una mirada absolutamente desbordada de humanidad y ternura hacia las criaturas de su universo histriónico.

\section{RELACIÓN DE OBRAS DE CALDERÓN SELECCIONADAS PARA ESTE ESTUDIO}

Hay que precisar que, además de las obras seleccionadas, existen otras en que también aparece el travestismo ${ }^{65}$, pero nos hemos centrado únicamente en aquellas en que este recurso funciona como mecanismo de transmisión ideológica relacionado con el tema de la mujer.

\section{Comedias}

Amor, honor y poder.

El castillo de Lindabridis.

La devoción de la cruz.

El escondido y la tapada.

Fieras afemina amor.

Hado y divisa de Leónido y Marfisa.

${ }_{65}$ A la lista que aparece en este epígrafe, hay que añadirle los siguientes títulos: el auto A María el corazón, y el entremés Las Carnestolendas. 
La hija del aire.

El José de las mujeres.

Las manos blancas no ofenden.

El monstruo de los jardines.

Los tres afectos de amor: piedad, desmayo y valor.

La vida es sueño.

Yerros de naturaleza y aciertos de la fortuna.

\section{Autos sacramentales}

El año santo de Roma.

El arca de Dios cautiva

El gran mercado del mundo.

La protestación de la fe.

\section{Teatro breve}

La garapiña.

El sacristán mujer.

\section{REFERENCIAS BIBLIOGRÁFICAS}

ABAD, Manuel (1985). «El disfraz en El monstruo de los jardines» en Hans Flasche, ed., Hacia Calderón. Séptimo Coloquio Anglogermano. Stuttgart: Franz Steiner.

AMEZCUA, José (1983). «Notas sobre el espacio en algunas obras de Calderón» en Calderón. Actas del Congreso Internacional sobre Calderón y el teatro español del Siglo de Oro, 1533-1544. Madrid: CSIC.

ARANGO, Manuel Antonio (1980). «El gracioso. Sus cualidades y rasgos distintivos en cuatro dramaturgos del siglo XVII: Lope de Vega, Tirso de Molina, Juan Ruiz de Alarcón y Pedro Calderón de la Barca» en Boletín del Instituto Caro y Cuervo, 35, 377-386.

ARELlaNO, Ignacio (1986). «La comicidad escénica en Calderón» en Bulletin Hispanique, LXXXVIII, 47-92.

ARMAS, Frederick A. de (1993). «Mujer y mito en el teatro clásico español: La viuda valenciana y La dama duende» en Lenguaje y Textos, 3, 57-72.

ARRónIZ, Othón (1977). Teatros y escenarios del Siglo de Oro. Madrid: Gredos.

ASCUNCE ARRIETA, José Ángel (1983). «Superposición temática y estructura radial en la literatura del barroco» en Calderón. Actas del Congreso Internacional sobre Calderón y el teatro español del Siglo de Oro, III, 1233-45. Madrid: CSIC.

ASENSIO, Eugenio (1971). Itinerario del entremés (De Lope de Vega a Quiñones de Benavente). Madrid: Gredos.

AUBRUN, Charles Vincent (1968). La comedia española, 1600-1680. Madrid: Taurus.

BALLARín DOMINGO, Pilar (1994). «De leer a escribir: instrucción y liberación de las mujeres» en M." del Mar Graña Cid, ed., Las sabias mujeres: educación, saber y autoría (siglos III-XVII). Madrid: Asociación cultural Al-Mudayna. 
BANCES CANDAMO, Francisco Antonio [1690]. Teatro de los teatros de los pasados y presentes siglos. Edición de Duncan Moir (1970). London: Tamesis Books.

BANDERA, Cesáreo (1975). Mímesis conflictiva. Ficción literaria y violencia en Cervantes y Calderón. Madrid: Gredos.

- (1982). «Historias de amor y dramas de honor» en McGaha, ed., Approaches to the theater of Calderón, 53-63. Washington, D. C.: University Press of America.

BARBEITO, Isabel (1992). Mujeres del Madrid Barroco. Voces testimoniales. Madrid: Dirección General de la mujer, Comunidad de Madrid.

BARREDA, Francisco de [1622]. «Invectiva a las comedias que prohibió Trajano y apología por las nuestras» en Federico Sánchez Escribano y Alberto Porqueras Mayo, eds. (1971). Preceptiva dramática española del Renacimiento y el Barroco. Madrid.

BARRIONUEVo, Jerónimo de [1654-1658]. Avisos de Jerónimo de Barrionuevo. B.A.E., t. 221 y 222. Madrid: Atlas (1968).

BOLUFER, M. (1994). «Los límites invisibles: modalidades de participación pública femenina en la sociedad ilustrada» en II Coloquio Internacional AEIHM: Mujeres $y$ ciudadanía. Santiago.

Bomli, P. W. (1950). La femme dans l'Espagne du siècle d'Or. La Haya.

BRAvo LozANo, J. (1996). «Fuentes para el estudio del trabajo femenino en la Edad Moderna: el caso de Madrid a fines del siglo XVII» en M. J. Matilla y M. Ortega, eds., El trabajo de las mujeres: siglos XVI-XX. Actas de las VI Jornadas del IUEM. Madrid: Universidad Autónoma.

BRAVO-VILlasante, Carmen (1944). «La realidad de la ficción negada por el gracioso» en Revista de Filología española, XXVIII.

- (1976). La mujer vestida de hombre en el teatro español. Madrid: SGEL.

BUEZo, Catalina (1997). «Mojigangas dramáticas calderonianas: síntesis y parodia de un género» en Pedro Calderón de la Barca. El teatro como representación y fusión de las artes. Anthropos, extra 1, 131-36. Barcelona: Proyecto A Ediciones en colaboración con GRISO de la Universidad de Navarra.

CALERO FERnÁNDEZ, M. a Ángeles (1996). «Análisis de las figuras femeninas en la literatura escrita en español: una bibliografía aproximativa» en La imagen de la mujer en la literatura, 185-214. Lleida: Facultad de Letras.

CALVI, Giulia (1995). La mujer barroca. Versión española de José Luis Gil Aristu. Madrid: Alianza Editorial.

CAMPS, Victoria (1994). Diccionario de mujeres célebres. Madrid: Espasa-Calpe.

CANAVAggio, Jean (1979). «Los disfrazados de mujer en la comedia» en La mujer en el teatro y la novela del siglo XVII. Actas del Segundo Coloquio de GESTE, 135 152. Toulouse-Le Mirail: Institut d'Études Hispaniques et Hispanoaméricaines.

CANET, José Luis (1995). «La seducción a través del discurso misógino hispánico-medieval» en Elena Real Ramos, El arte de la seducción en el mundo romántico medieval y renacentista. Universidad de Valencia.

CARO BAROJA, Julio (1968). El concepto del honor en la sociedad mediterránea. Barcelona: Labor.

- (1978). Las formas complejas de la vida religiosa. (Religión, sociedad y carácter en la España de los siglos XVI y XVII). Madrid: Akal

CASTRO, Américo (1916). «Algunas observaciones acerca del concepto del honor en los siglos XVI y XVII» en Revista de filología española, III, 1-50 y 357-386.

- (1972). De la Edad Conflictiva. Crisis de la cultura española en el siglo XVII. Madrid: Taurus. Tercera Edición.

CASTRO Y RosSI, A. (1881). Discurso acerca de las costumbres públicas y privadas de los españoles en el siglo XVII, fundado en el estudio de las comedias de Calderón. Madrid: Academia de C. M. y P. 
CÁtedra, Pedro M. (1989). Amor y pedagogía en la Edad Media. Universidad de Salamanca.

CATELli, Nora (1991). Diccionario de mujeres célebres. Barcelona: Lumen.

CEPEDA GóMEZ, Paloma (1986). «La situación jurídica de la mujer en España durante el Antiguo Régimen y Régimen liberal» en Ordenamiento jurídico y realidad social de las mujeres. Actas de las IV Jornadas de Investigación Interdisciplinaria. Edición preparada por M. ${ }^{a}$ Carmen García Nieto. Madrid: Universidad Autónoma.

CONNOR, Catherine (1994). «Teatralidad y resistencia: el debate sobre la mujer vestida de hombre» en Juan Villegas, ed., Encuentros y desencuentros de culturas: desde la Edad Media al siglo XVIII. Actas Irvine-92. Asociación Internacional de Hispanistas, III, 139-145. Universidad de California.

COTARELO (1904). Bibliografía de las controversias sobre la licitud del teatro en España. Madrid: Revista de Archivos, Bibliotecas y Museos.

CREMADES GriÑáN, Carmen María (1986). «Los bienes de las mujeres aportados al matrimonio. Estudio de la evolución de la dote en la Edad Moderna» en Ordenamiento jurídico y realidad social de las mujeres. Actas de las IV Jornadas de Investigación Interdisciplinaria, 137-147. Edición preparada por M. ${ }^{a}$ Carmen García Nieto. Madrid: Universidad Autónoma.

DEFOURNEAUX, Marcellin (1983). La vida cotidiana en la España del Siglo de Oro. Barcelona: Vergara.

DELEITO Y PINUELA, José (1952). La vida religiosa española bajo el cuarto Felipe: Santos y pecadores. Madrid: Espasa-Calpe.

- (1966). La mujer, la casa y la moda. Madrid: Espasa-Calpe.

DELPECH, François (1979). «La leyenda de la Serrana de la Vera» en La mujer en el teatro y la novela del siglo XVII. Actas del Segundo Coloquio de GESTE, 25-37. Toulouse-Le Mirail: Institut d'Études Hispaniques et Hispanoaméricaines.

DÉODAT-KESSEDJIAN, Marie-Françoise (1996). «Honor, amor y silencio. La mujer en algunas obras de Calderón» en Agustín de la Granja y Juan Antonio Martínez Berbel, eds., Mira de Amescua en candelero. Actas del Congreso Internacional sobre Mira de Amescua y el teatro español del siglo XVII, 107-120. Universidad de Granada.

Díaz-PlajA, F. (1963). El amor en las letras españolas. Madrid: Edit. Nacional.

Diccionario de la lengua española (1992). Real Academia Española. Madrid: EspasaCalpe.

Diego González, J. Natividad de, y África León SAlmerón. Compendio de indumentaria española. Madrid.

DíEZ BORQUE, J. M. (1975). Tratado histórico sobre el origen y el progreso de la comedia y el histrionismo en España. Barcelona: Labor.

- (1976). Sociología de la comedia española del siglo XVII. Madrid: SGEL.

- (1979). «El feminismo de doña María de Zayas» en La mujer en el teatro y la novela del siglo XVII. Actas del Segundo Coloquio de GESTE, 61-87. Toulouse-Le Mirail: Institut d'Études Hispaniques et Hispanoaméricaines.

- (1990). La vida española en el Siglo de Oro según los extranjeros. Barcelona: Ediciones del Serbal.

DOMíNGUEZ DE PAZ, Elisa M. ${ }^{\text {a }}$ (1996). «Reflexiones en torno al feminismo en la obra dramática de Juan de la Hoz y Mota: La más valiente guerrera» en Ignacio Arellano et alii, eds., Studia Aurea. Actas del III Congreso de AISO (Toulouse, 1993). II Teatro, 130-139. Toulouse-Pamplona: GRISO-LEMSO.

DOMíngUeZ ORTIZ, A. (1973a). El Antiguo Régimen: los Reyes católicos y los Austrias. Madrid: Alfaguara.

- (1973b). Las clases privilegiadas en el Antiguo Régimen. Madrid: Istmo.

- (1992). «La mujer española en una época en crisis» en La voz del silencio. I. Siglos VIII-XVIII. Madrid: Asociación Cultural Al-Mudayna. 
EGIDO, Aurora (1989). La fiera, el rayo y la piedra. Madrid: Cátedra.

Elliot, J. H. (1999). En colaboración con L. W. B. Brockliss. El mundo de los validos. Madrid: Taurus.

FACIO, Ángel (1997). «Don Pedro Calderón, precursor del vodevil» en La década de oro en la comedia española: 1630-1640. Actas de las XIX Jornadas de Teatro Clásico. Almagro, julio de 1996, 159-166. Edición cuidada por Felipe B. Pedraza Jiménez y Rafael González Cañal. Universidad de Castilla-La Mancha. Festival de Almagro.

FALIU-LACOURT, Christiane (1979). «La madre en la comedia» en La mujer en el teatro y la novela del siglo XVII. Actas del Segundo Coloquio de GESTE, 38-59. ToulouseLe Mirail: Institut d'Études Hispaniques et Hispanoaméricaines.

FARGE, A. y DAVIS, N. (1992). Historia de las mujeres: del Renacimiento a la Edad Moderna. Madrid.

FERNÁNDEZ VARGAS, Valentina (1983). «Notas sobre algunos personajes femeninos en la obra de D. Pedro Calderón de la Barca» en L. García Lorenzo, ed., Calderón. Actas del Congreso Internacional sobre Calderón y el teatro español del Siglo de Oro, II, 1013-1024. Madrid: CSIC.

- (1986). En colaboración con M. V. LÓPEZ CORDÓN, «Mujer y régimen jurídico en el Antiguo Régimen: una realidad jurídica y realidad social de las mujeres» en Actas de las IV Jornadas del IUEM, 13-40. Universidad Autónoma de Madrid.

GARCÍA LORENZO, Luciano (1984). «Elementos grotescos en el teatro de Calderón» en IV Table ronde sur le théâtre espagnol du XVII-XVIII siècle. Paris: Université.

GARCíA MARTín, Manuel (1980). Cervantes y la comedia española del siglo XVII. Salamanca: Universidad.

GASCÓN VERA, Elena (1992). «Narcisismo, cultura y religión: el paradigma de lo masculino y lo femenino en El príncipe constante» en Un mito nuevo: la mujer como sujeto/objeto literario, 187-197. Madrid: Pliegos.

GAYLORD RANDEL, Mary (1983). «Amor y honor a través del espejo» en Calderón. Actas del Congreso Internacional sobre Calderón y el teatro del Siglo de Oro, II, 869-79. Madrid: CSIC.

Gil AmbronA, A. (1987). «Entre la oración y el trabajo: las ocupaciones de las otras esposas. Siglos XVI-XVII» en M. J. Matilla y M. Ortega, eds., El trabajo de las mujeres: siglos: XVI-XVII, 57-67. Madrid: Universidad Autónoma.

GoNZÁleZ GoNZÁleZ, Luis M. (1994-95). «La mujer en el teatro del Siglo de Oro español» en Teatro. Revista de Estudios Teatrales, $\mathrm{n}^{\circ}$ 6-7, 41-70. Universidad de Alcalá de Henares.

GonzÁlez Velasco, M. ${ }^{a}$ del Pilar (1989). Variaciones de Segismundo en la obra de Calderón. Universidad de Salamanca.

GRAÑA CID, M.a del Mar (1991). En colaboración con Ángela Muñoz Fernández, eds., Religiosidad femenina: expectativas y realidades (ss. VIII-XVIII). Madrid: AlMudayna.

- Ed. (1994). Las sabias mujeres: educación, saber y autoría (siglos III-XVII). Asociación cultural Al-Mudayna.

GREEN, Otis H. (1969). España y la tradición occidental. El espíritu castellano en la literatura desde el Cid hasta Calderón. Madrid: Gredos. 4 tomos.

GÜNTERT, Georges (1977). «El gracioso en Calderón: Disparate e ingenio» en Cuadernos Hispanoamericanos, 324, 440-453.

GUTIÉRREZ NiETO, Juan Ignacio (1983). «Honra y utilidad social (En torno a los conceptos de honor y honra)» en Calderón. Actas del Congreso Internacional sobre Calderón y el teatro del Siglo de Oro, II, 881-895. Madrid: CSIC.

HERMENEGILDO, Alfredo (1995). Juegos dramáticos de la locura festiva. Pastores, simples, bobos y graciosos del teatro clásico español. Palma de Mallorca: José de Olañeta. Serie Oro Viejo. 
HERNÁNDEZ ARAICO, Susana (1986). «El gracioso y la ruptura de la ilusión escénica» en Imprévue, 1, 61-73.

HERPOEL, Sonja (1989). «Bajo la amenaza de la Inquisición: escritoras españolas en el Siglo de Oro» en España, teatro y mujeres. Estudios dedicados a Henk Oostendorp, 123-131. Amsterdam: Rodopi.

HeSSE, Everett W. (1987). La mujer como víctima y otros ensayos. Barcelona: Pulvill.

- (1989). «Obstáculos al amor erótico y al matrimonio en la comedia de Calderón» en Estudios sobre Calderón y el teatro de la Edad de Oro. Homenaje a Kurt y Roswitha Reichenberger, 63-80. Edición a cargo de Francisco Mundi Pedret. Recopilación: Alberto Porqueras Mayo y José Carlos de Torres. Barcelona: PPU.

HoNIG, Edwin (1972). Calderón and the Seizures of Honor. Cambridge: Harvard University Press.

Huerta Calvo, Javier (1983). «El discurso popular en el siglo XVII: Calderón y los géneros teatrales ínfimos» en Calderón. Actas del Congreso Internacional sobre Calderón y el teatro del Siglo de Oro, 805-15. Madrid: CSIC.

- (1995). El nuevo mundo de la risa. Estudios sobre el teatro breve y la comicidad en los Siglos de Oro. Palma de Mallorca: José de Olañeta.

HuFtoN, O. (1992). «Mujeres, trabajo y familia» en Historia de las mujeres: del Renacimiento a la Edad Moderna. Madrid.

IMIRIZALDU, J. (1977). Monjas y beatas embaucadoras. Madrid: Editora Nacional.

JAMMES, Robert (1980). «La risa y su función social en el Siglo de Oro» en Risa y sociedad en el teatro español del Siglo de Oro, 3-11. Toulouse: Universidad de Toulouse-Le Mirail.

JULIÁ MARTíneZ, Eduardo (1930). Yerros de naturaleza y aciertos de la fortuna. Madrid: Hernando.

KING, Margaret L. (1993). Mujeres renacentistas. La búsqueda de un espacio. Versión española de Aurora Lanzardo. Madrid: Alianza Editorial.

LANOT, Jean Raymond (1979). «El feminismo de A. Hurtado de Mendoza» en La mujer en el teatro y la novela del siglo XVII. Actas del Segundo Coloquio de GESTE, 113131. Toulouse-Le Mirail: Institut d'Études Hispaniques et Hispanoaméricaines.

LARRAÑAGA DonÉZAR, Maravillas (1989). El escondido y la tapada. Barcelona: PPU.

LEY, Charles David (1954). El gracioso en el teatro de la península. Madrid: Revista de Occidente.

LoBATO, M. ${ }^{a}$ Luisa (1994). «Ensayo de una bibliografía anotada del gracioso en el teatro español del Siglo de Oro» en Criticón, 60, 149-170.

- (1997). «Mecanismos cómicos en los entremeses de Calderón» en Pedro Calderón de la Barca. El teatro como representación y fusión de las artes. Anthropos, extra 1, 136-42. Barcelona: Proyecto A Ediciones en colaboración con GRISO de la Universidad de Navarra.

- (1998). «Dos nuevos entremeses para Juan Rana» en Christoph Strosetzki, ed., Studia Hispanica. Teatro Español del Siglo de Oro. Teoría y práctica, 191-236. Vervuert: Iberoamericana.

LÓPEZ CORDÓN, V. (1984). «La literatura religiosa y moral como conformadora de la mentalidad femenina: 1760-1860» en La mujer en la historia de España: siglos XVI al XX. Actas de las II Jornadas de Investigación Interdisciplinar sobre la mujer. Madrid: Universidad Autónoma.

LÓPEZ DE JOSÉ, Alicia (1997). «Sobre el modo en que los caballeros han de galantear a las damas y entrar en Palacio y en el aposento de la Reina» en La década de oro en la comedia española: 1630-1640. Actas de las XIX Jornadas de teatro clásico de Almagro, 213-228. Servicio de Publicaciones de la Universidad de Castilla-La Mancha. 
Losada GoyA, José Manuel (1993a). L’Honneur au théâtre. París: Klincksieck.

- (1993b). «La concepción del honor en el teatro español y francés del siglo XVII: problemas de metodología» en Manuel García Martín, ed., Estado actual de los estudios sobre el Siglo de Oro. Actas del II Congreso de la Asociación Internacional del Siglo de Oro, 589-596. Salamanca: Ediciones Universidad de Salamanca.

- (1997). «Calderón y su honor calidoscópico» en Pedro Calderón de la Barca. El teatro como representación y fusión de las artes. Revista Anthropos, extra 1, 65-72. Barcelona: Proyecto A Ediciones en colaboración con GRISO de la Universidad de Navarra. Coordinadores: Ignacio Arellano y Ángeles Cardona.

LozoyA, Teófilo de (1990). El Conde Duque de Olivares. Barcelona: Crítica.

LUJÁN, Néstor (1988). La vida cotidiana en el Siglo de Oro español. Barcelona: Planeta.

MAESO, Ángeles (1989). «Notas para una revisión de lo femenino en la literatura» en David Valjalo, ed., Canción de Marcela. Mujer y cultura en el mundo hispánico. Madrid: Orígenes.

MARAVAll, José Antonio (1978). «Seminario sobre la cultura del Barroco» en La mujer en el teatro y la novela del siglo XVII. Actas del segundo coloquio de GESTE, 3-22. Toulouse-Le Mirail: Institut d'Études' Hispaniques et Hispanoaméricaines.

-(1979). Poder, honor y élites en el siglo XVII. Madrid: Siglo XXI de España.

MARTÍNEZ BLASCO, Ángel (1995). Las manos blancas no ofenden. Kassel: Reichenberger.

MASON, T. R. A. (1985). «La sexualidad pervertida?. Las manos blancas no ofenden» en Hans Flasche, ed., Hacia Calderón. Séptimo Coloquio Anglogermano. Stuttgart: Franz Steiner.

McKendrICK, Melveena (1974). Woman and Society in the Spanish Drama of the Golden Age (A Study of the mujer varonil). Cambridge: University Press.

- (1991). «El espacio simbólico en Calderón» en Hans Flasche, ed., Hacia Calderón. Noveno Coloquio Anglogermano. Stuttgart: Franz Steiner.

MENÉNDEZ PELAYo, Marcelino (1910). Calderón y su teatro. Madrid: Revista de Archivos.

MENÉNDEZ PIDAL, Ramón (1937). «Del honor en el teatro español» en De Cervantes $a$ Lope de Vega. Madrid: Espasa-Calpe. Colección Austral, n. ${ }^{\circ} 120$.

MoIR, Duncan W. (1970). Teatro de los teatros de los pasados y presentes siglos. London: Tamesis Books.

MORAlES, M. ${ }^{\text {a }}$ Victoria (1983). «Función de la figura femenina en la comedia de enredo de Calderón» en Horizontes, XXVII, 53, 5-20.

Morón ARroyo, Ciriaco (1982). Calderón. Pensamiento y teatro. Santander: Sociedad Menéndez Pelayo.

NAVARRO GonZÁlEZ, Alberto (1983). «Comicidad del lenguaje en el teatro de Calderón» en Ibero Romania, 14, 116-132. Munich.

NELKEN, Margarita (1930). Las escritoras españolas. Barcelona: Labor.

O'CONNOR, Thomas Austin (1983). «El optimismo de Ni amor se libra de amor» en L. GARCÍA LOREnZo, ed., Calderón. Actas del Congreso Internacional sobre Calderón y el teatro español del Siglo de Oro, I, 533-540. Madrid: CSIC.

OÑATE, M. a del Pilar (1938). El feminismo en la literatura española. Madrid: EspasaCalpe.

OROZCO DíAZ, Emilio (1969). El teatro y la teatralidad del Barroco. Barcelona: Planeta.

- (1983). «Sentido de continuidad espacial y desbordamiento expresivo en el teatro de Calderón. El soliloquio y el aparte» en Calderón. Actas del Congreso Internacional sobre Calderón y el teatro del Siglo de Oro, I, 125-164. Madrid: CSIC.

ORTEGA LóPEZ, Margarita (1995). «Las mujeres de Madrid en el siglo XVII» en Las mujeres de Madrid como agentes de cambio social. Madrid: Universidad Autónoma. 
- (1997). «Las mujeres en la España Moderna» en Elisa Garrido, ed., Historia de las mujeres en España, 247-344. Madrid: Síntesis.

PAILlER, Claire (1974). La question d'amour dans les comedias de Calderón de la Barca. París: Les Belles Lettres.

- (1980). «El gracioso y los guiños de Calderón: apuntes sobre autoburla e ironía crítica» en Risa y sociedad en el Teatro español del Siglo de Oro. Actas du 3 Colloque du Groupe d'Études sur le Théâtre Espagnol, 33-48. Toulouse.

PARKER, Alexander A. (1986). La filosofía del amor en la literatura española (14801680). Madrid: Cátedra.

- (1991). En colaboración con Deborah Kong, eds., La imaginación y el arte de Calderón. Ensayos sobre las comedias. Madrid: Cátedra. Serie: crítica y estudios literarios.

PELLICER, Casiano [1804]. Tratado histórico sobre el origen y progreso de la comedia y el histrionismo en España. Edición de J. M. Díez Borque (1975). Barcelona: Labor.

PEREIRA, Óscar (1989). «Teatrum mundi: Cervantes y Calderón» en Anales cervantinos, XXVII, 187-202. Madrid: CSIC.

PÉREZ MOLINA, Isabel (1994). «Las mujeres y el matrimonio en el derecho catalán moderno» en Las mujeres en el Antiguo Régimen. Imagen y realidad. Barcelona: Icaria.

PÉREZ RIOJA, José Antonio (1983). El amor en la literatura. Madrid: Tecnos.

PFANDL, Ludwig (1994). Introducción al Siglo de Oro. Cultura y costumbres del pueblo español de los siglos XVI y XVII. Madrid: Visor.

PORRO HERRERA, M. ${ }^{a}$ Josefa (1995). Mujer «sujeto»/mujer «objeto» en la literatura española del Siglo de Oro. Universidad de Málaga: Atenea.

PROFETI, M. ${ }^{a}$ Grazia (1980). «Código ideológico-social, medios y modos de la risa en la comedia del siglo XVII» en Risa y sociedad en el Siglo de Oro. Toulouse: Universidad de Toulouse-Le Mirail.

- (1995). «Mujer y escritura en la España del Siglo de Oro» en Iris Zavala, ed., Breve historia feminista de la literatura española. II: La mujer en la literatura española, 235-284. Madrid: Anthropos-Comunidad de Madrid.

REAL RAMOS, Elena (1995). El arte de la seducción en el mundo romántico medieval y renacentista. Universidad de Valencia.

REDONDO, Agustín (1995). Relations entre hommes et femmes en Espagne aux XVI et XVII siècles. Paris: Publications de la Sorbonne (Travaux du CRES).

REgAlADO, Antonio (1995). Calderón. Los orígenes de la modernidad. 2 volúmenes. Barcelona: Destino.

Reglá, J. (1971). «La época de los tres primeros Austrias» en Historia de España y América. Barcelona: Vicens Vives.

RIVERA DE ROSALES, Jacinto (1997). Sueño y realidad. La ontología poética de Calderón de la Barca. Hildesheim: Georges Olms.

RóDENAS MARTíNEZ, M. ${ }^{a}$ Gloria (1992). En colaboración con Susana M. ${ }^{a}$ VICENT COLONQUES, «La cultura escrita y la mujer» en La voz del silencio. I: Siglos VIIIXVIII. Madrid: Asociación Cultural Al-Mudayna.

Rodríguez CuAdros, Evangelina (1982). En colaboración con Antonio Tordera. Pedro Calderón de la Barca. Entremeses, jácaras y mojigangas. Madrid: Castalia.

- (1997). «El arte calderoniano del entremés» en Pedro Calderón de la Barca. El teatro como representación y fusión de las artes. Anthropos, extra 1, 126-131. Barcelona: Proyecto A Ediciones en colaboración con GRISO de la universidad de Navarra.

- (1998). La técnica del actor español en el Barroco. Hipótesis y documentos. Madrid: Castalia. 
Romera NAVARro, M. (1934). «Las disfrazadas de varón en la comedia» en Hispanic Review, 2, 269-286.

RuANO DE LA HAZA, José M. (1994a). En colaboración con John Allen. Los teatros comerciales del siglo XVII y la escenificación de la comedia. Madrid: Castalia.

-(1994b). «La comedia y lo cómico» en Del horror a la risa. Los géneros dramáticos clásicos. Homenaje a Christian Faliu-Lacourt, 269-285. Kassel: Reichenberger.

RULl, Enrique (1980). La vida es sueño (comedia, auto y loa). Madrid: Alhambra.

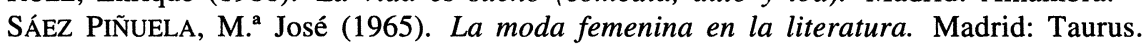

SÁNCHEZ, Alberto (1957). «Reminiscencias cervantinas en el teatro de Calderón» en Anales cervantinos, 6, 262-270.

SÁNCHEZ EsCRIBANO, Federico y PORQueras MAYo, Alberto, eds. (1971). Preceptiva dramática española del Renacimiento y el Barroco. Madrid: Gredos.

SÁNCHEZ LORA, J. L. (1988). Mujeres, conventos y formas de religiosidad barroca. Madrid: Fundación Universitaria Española.

SÁNCHEZ LlAMA, Íñigo (1993). «La lente deformante: la visión de la mujer en la literatura de los Siglos de Oro» en Estado actual de los estudios sobre el Siglo de Oro. Actas del II Congreso Internacional de Hispanistas del Siglo de Oro, II, 941-47. Universidad de Salamanca.

SÁNCHEZ ORTEGA, M. H. (1984). «La mujer, el amor y la religión en el Antiguo Régimen» en Durán, M. A., ed., La mujer en la historia de España, 35-58. Madrid.

SANTOMAURO, María (1985). «Los personajes femeninos en las comedias religiosas de Calderón» en Revista Estudios, XLI, 7-50.

SEgURA GRAíño, Cristina (1996). En colaboración con Gloria Nielfa, eds., Entre la marginación y el desarrollo: Mujeres y hombres en la Historia. Homenaje a M. Carmen García Nieto. Madrid: Orto.

- (1997). La historia de las mujeres en el nuevo paradigma de la Historia. Madrid: Al-Mudayna.

- (1998). Diccionario Espasa de mujeres célebres. Madrid: Espasa-Calpe.

SERRALTA, Frederic (1990). «Juan Rana, homosexual» en Criticón, 50, 81-92.

- (1994). «La risa y el actor: el caso de Juan Rana» en Del horror a la risa. Los géneros dramáticos clásicos. Homenaje a Christian Faliu-Lacourt, 287-302. Kassel: Reichenberger.

SUÁREZ MIRAMÓN, Ana (1993a). «Bances Candamo: hacia un teatro ilustrado y polémico» en Revista de literatura, LV, 109, 5-54.

- (1993b). «La función cómica del personaje Guardainfante en el teatro de Rojas» en Homenaje al profesor José Fradejas Lebrero, I, 453-467. Madrid: UNED.

- (1999). «Cervantes en los autos Sacramentales de Calderón» en Anales Cervantinos, XXV, 511-537. Madrid. CSIC. Centro de Estudios Cervantinos.

Thompson, Peter (1998). «Juan Rana, a Gay Golden Age Gracioso» en Eduard H. Friedman, H. J. Manzari y Donald D. Miller, eds., A Society on Stage. Essays on Spanish Golden Drama, 239-251. Nueva Orleans: University Press of the South.

TORRES, Victoria B. (1987). El castillo de Lindabridis. Pamplona: Universidad de Navarra.

VALBUENA BRIONES, Ángel (1982). «Los libros de caballerías en el teatro de Calderón» en Hacia Calderón. Quinto Coloquio Anglogermano, 1-8. Stuttgart: Franz Steiner.

- (1987). Calderón de la Barca. Obras completas. Tomo I: Comedias. Madrid: Aguilar. Segunda reimpresión de la edición de 1960.

- (1991). Calderón de la Barca. Obras completas. Tomo II: Dramas. Madrid: Aguilar. Tercera reimpresión de la edición de 1969.

VAlbuena PRAT, Ángel (1970). Edición de La devoción de la cruz. Madrid: EspasaCalpe. 
- (1991). Obras completas de Calderón de la Barca. Tomo III: Autos sacramentales Madrid: Aguilar. Segunda reimpresión de la edición de 1967.

VAREY, J. E. (1971). «La creación deliberada de la confusión: estudio de una diversión de Carnestolendas de 1623» en Homenaje a William L. Fichter, 745-754. Madrid: Castalia.

VIGIL, Mariló (1986). La vida de las mujeres en los siglos XVI y XVII. Madrid: Siglo XXI de España.

VITSE, Marc (1995). «El segundo hálito del teatro» en Jean Canavaggio, ed., Historia de la literatura española. Tomo III: Siglo XVII, 197-224. Barcelona: Ariel.

VVAA. (1986). Ordenamiento jurídico y realidad social de las mujeres, siglos XVI a $X X$. Actas de las IV Jornadas de Investigación Interdisciplinarias. Madrid: Universidad Autónoma.

VVAA. (1987). Literatura y vida cotidiana. Actas de las IV Jornadas del Instituto Universitario de Estudios de la Mujer (IUEM). Madrid: Universidad Autónoma.

VVAA. (1988). «La mujer en España: historia de una marginación» en Historia 16. Madrid.

VVAA. (1992). Historia de las mujeres del Renacimiento a la Edad Moderna. Madrid: Taurus.

VVAA. (1994a). Las mujeres en el Antiguo Régimen. Barcelona: Icaria.

- (1994b). Textos para la Historia de las mujeres en España. Madrid: Cátedra.

- (1994c). El gracioso en el teatro español del Siglo de Oro. Actas del VI coloquio de GESTE, en Criticón, 60. Toulouse: Institut d'Études Hispaniques.

WAlthaus, Rina (1993). La mujer en la literatura hispánica de la Edad Media y el Siglo de Oro. Amsterdam: Rodopi.

WEXLER, Frederick Sidney (1966). Comedia famosa de la devoción de la cruz de don $P$. Calderón de la Barca. Tesis de doctorado por la Universidad de Nueva York. Salamanca: Anaya.

WILSON, Edward M. (1976). La vida es sueño. Reimpreso en Manuel Durán y Roberto González Echeverría, Calderón y la crítica. Historia y antología, vol. I. Madrid: Gredos.

ZAVALA, Iris (1995). Breve historia feminista de la literatura española (en lengua castellana). II La mujer en la literatura española. Modos de representación desde la Edad Media hasta el siglo XVII. Madrid/Puerto Rico: Dirección General de la Mujer/Anthropos/Universidad de Puerto Rico. 